Vol. 24, No. 4, pp. 368 385, 2021.

\title{
Development of Ammonia Fueled Solid Oxide Fuel Cells
}

\author{
Jong-Eun Hong ${ }^{1,2 \dagger}$, Seung-Bok Lee ${ }^{1,2}$, Dong Woo Joh ${ }^{1}$, Hye-Sung Kim ${ }^{1}$, Tak-Hyoung Lim ${ }^{1,2}$, \\ Seok-Joo Park ${ }^{1,2}$, Rak-Hyun Song ${ }^{1,2}$
}

${ }^{1}$ Fuel Cell Laboratory, Korea Institute of Energy Research, 152 Gajeong-ro, Yuseong-gu, Daejeon, Republic of Korea ${ }^{2}$ Hydrogen Energy Engineering, University of Science and Technology, 217 Gajeong-ro, Yuseong-gu, Daejeon, Republic of Korea

\section{암모니아 연료용 고체산화물연료전지 개발}

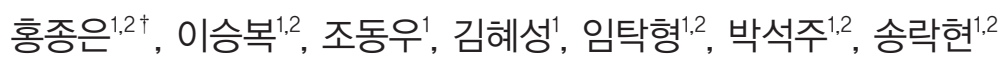 \\ ${ }^{1}$ 연료전지연구실, 한국에너지기술연구원 \\ 2한국과학기술연합대학교대학원 수소에너지공학
}

(Received December 13, 2021; Revised December 23, 2021; Accepted December 24, 2021)

\begin{abstract}
s
Solid oxide fuel cells (SOFCS) can generate electricity through an electrochemical conversion of the chemical energy of fuels including hydrogen, hydrocarbons, and biogas because of high operation temperatures. Ammonia has recently been considered as a promising hydrogen carrier that is relatively convenient to store and transport and can be decomposed into hydrogen and nitrogen with no carbon emission via catalytic cracking. Thus, much effort has been made to utilize ammonia as a clean fuel to SOFCs for power generation at high efficiency. This review is aiming at delivering the current progress of developing high temperature ceramic fuel cells fed with ammonia, particularly more focused on the achievements of a direct ammonia fueled SOFC (DA-SOFC) to shed light on the challenges of degrading the performance and durability. The problems are primarily attributed to a lack of rational catalysts, thermal imbalance, and the evolution of nitrides on the components including the $\mathrm{Ni}$ based anode, Ni mesh as current collector, and stainless steels of metallic interconnect that are exposed to the ammonia fuel environment incurring microstructural deformations and electrical and electrochemical deteriorations. Lastly, strategic pathways to overcome the inadequate performance and the instability are suggested to accomplish a commercialization of DA-SOFCs.
\end{abstract}

Keywords: Solid oxide fuel cells, Ammonia, Hydrogen carrier, Degradation, Nitriding

†Corresponding Author: jehong@kier.re.kr 


\section{1. 서론}

현대 사회는 세계 인구의 증가에 따라 지속적으로 증 가하는 에너지 수요를 충족시키기 위해 주로 화석연료 를 통해 에너지를 생산, 공급해 왔다. 화석연료의 대규 모 활용으로 급격한 산업화와 도시화를 이루었지만 $\mathrm{NO}_{\mathrm{x}}$ 나 $\mathrm{CO}_{2}$ 와 같은 오염물질의 배출이 급격히 증가하여 대 기오염이나 지구온난화 가속화 등 대규모 환경 문제가 발생하고 있다. 따라서 국제 사회는 에너지 수요와 기후 변화에 능동적으로 대응하기 위해 탄소중립사회 실현을 지향하고 있으며 이를 위해 에너지 생산 시 풍력이나 태 양광처럼 청정 기술로 각광받고 있는 재생에너지 비율 을 증가시키고 있다. ${ }^{[1]}$ 하지만 재생에너지 기술은 외부 환경이나 지질학적 요인에 의존하기 때문에 간헐적으로 발전이 가능하다는 한계를 갖고 있다. ${ }^{[2]}$ 따라서 상시 발 전이 가능하고 오염물질 배출이 적은 연료전지 발전 기 술이 각광받고 있다.

연료전지는 전기화학적 반응을 통해 연료의 화학에너 지를 직접 전기에너지로 변환하는 전기화학장치로써 내 연기관에 비해 에너지 변환 효율이 높고 오염물질이나 온실가스 배출을 현저히 감소시킬 수 있다. 또한 연료전 지는 재생에너지에 비해 생산하는 에너지 밀도가 높아 도심지역의 분산전원으로써 효용성이 매우 높은 것으로 평가받고 있다. ${ }^{[1,3]}$ 연료전지는 작동온도와 전해질의 종 류에 따라 대표적으로 고분자전해질연료전지(ProtonExchanging Membrane Fuel Cell: PEMFC), 알칼리 형연료전지(Alkaline Fuel Cell: AFC), 인산형연료전 지(Phosphoric Acid Fuel Cell: PAFC), 용융탄산염연 료전지(Molten Carbonate Fuel Cell: $\mathrm{MCFC}$ ) 및 고체 산화물연료전지(Solid Oxide Fuel Cell: SOFC) 등으 로 구분된다. 그 중 $\mathrm{SOFC}$ 는 이온 전도성을 갖는 세라 믹 전해질을 사용하여 $600-800^{\circ} \mathrm{C}$ 의 고온에서 작동하 는 연료전지로서 여러 연료전지들 중 전기변환 효율이 45-60\%로 가장 높으며 수소뿐만 아니라 도시가스, 프 로판가스 등 탄화수소계 연료와 바이오매스나 바이오가 스 등 다양한 연료를 부분적으로 개질하여 이용하거나 별도의 개질 없이 직접 내부 개질을 통해 활용할 수 있
다. ${ }^{[3,4]}$ 다만, 현재 국내에 운전 중인 연료전지의 대부분 은 도시가스를 연료로 공급하여 발전하기 때문에 운전 중 반응 부산물로써 $\mathrm{CO}_{2}$ 가 배기가스로 배출되기 때문에 탄소중립실현과 수소경제 활성화를 위해서는 생성되는 $\mathrm{CO}_{2}$ 를 포집, 저장, 활용하는 CCUS(Carbon Capture, Utilization, and Sequestration) 기술과 연계하거나 무탄소 연료의 사용이 반드시 필요할 것이다. ${ }^{[5]}$

수소를 연료로 작동하는 $\mathrm{SOFC}$ 는 열과 전기를 생산하 면서 반응 생성물로 물을 배출하기 때문에 미세먼지나 온실가스 등 유해물질 배출이 없고 ${ }^{[6,7]}$, 재생에너지를 이 용하여 생산한 청정 수소를 이용할 경우 탄소중립 발전 을 실현할 수 있다. ${ }^{[8]}$ 하지만 수소 연료를 연료전지에 적 극 활용하기 위해서는 수소 저장 및 운송에 대한 한계 극복이 필수적이다. ${ }^{[9]}$ 현재 대표적인 수소 저장 방법은 액화시켜 저장하거나 고압 용기에 압축하여 저장하는 방식인데 상당한 초기 자본 투자가 필요할 뿐만 아니라, 부피당 저장 용량이 작아 대용량 저장에 한계가 있다. 또한 수소 운송을 위한 효율적인 체계를 구축하기 위해 서도 상당한 초기 투자가 필요하며 장거리 운송이 어려 운 문제가 있다. ${ }^{[10,11]}$ 최근에는 이러한 문제 해결을 위해 수소를 다른 화합물 형태로 변환하여 부피당 저장 용량 을 증가시키고 저장이나 운송 등에 소요되는 경제적 비 용을 줄이기 위한 수소 캐리어(hydrogen carrier) 연구 가 활발히 진행되고 있다. ${ }^{[5,8-10]}$

그 중 암모니아 $\left(\mathrm{NH}_{3}\right)$ 는 $17.6 \mathrm{wt} \%$ 의 수소 함량을 가 지며 $75 \%$ 수소와 $25 \%$ 질소의 혼합가스로 분해될 수 있 어 탄소 배출이 없는 수소 생산이 가능하다. 또한 상온 에서 쉽게 액화하기 때문에 액화수소보다 단위 부피당 수소 저장 밀도가 1.7 배 이상 높으며, 이미 전 세계적으 로 운송 및 저장을 위한 기반시설과 체계가 원활히 구축 되어 있다. ${ }^{[12,13]}$ 국제에너지기구(International Energy Agency: IEA)는 재생에너지가 풍부한 지역에서 그린 암모니아를 생산하여 운송하는 재생에너지 기반의 에너 지 무역을 화석연료 대신 제안한 바 있으며, 국제해사기 구(International Maritime Organization: IMO)는 저 탄소 배출 선박 연료로 암모니아를 주목하고 있다. 한편 암모니아는 그 자체로 암모니아 가스터빈이나 석탄/암 
모니아 혼소 발전 등과 같은 내연기관 및 연소로의 연료 또는 연료전지의 연료로 사용되어 청정 발전을 통한 온 실가스 배출 저감에 기여할 수 있는 등 다양한 잠재력을 가지고 있기 때문에 수소 캐리어로써 크게 주목받고 있 다. ${ }^{[5,14-16]}$

따라서 본고에서는 암모니아 연료를 사용하는 $\mathrm{SOFC}$ 기술 개발 현황을 살펴보고, 특히 암모니아를 직접 연료 극에 공급하여 발전하는 기술에 대한 선행연구 결과와 문제점들을 고찰하여 상용화를 달성하기 위한 방안을 논의하였다.

\section{2. 암모니아 연료용 SOFC}

암모니아 연료용 SOFC 기술은 암모니아를 분해 (cracking 또는 decomposition)한 후 생성된 수소와 질소의 혼합가스 중 수소를 연료로 활용하는 기술로써 $\mathrm{SOFC}$ 가 갖는 고효율 발전 특성과 암모니아 연료가 갖 는 저장 및 운송의 편리성을 만족하며 탄소 배출이 없는 차세대 청정 발전기술로 주목받고 있다. 암모니아 연료 를 $\mathrm{SOFC}$ 에 이용하기 위해 Fig. 1과 같이 세 가지 유형 의 시스템 구성방안에 대한 기술 개발이 진행되고 있다. Fig. 1(a)는 별도의 암모니아 분해장치(cracker)를 통해 식 (1)과 같이 수소와 질소로 완전히 분해시켜 연료로 공 급한 후 식 (2)와 같이 연료극에서 선택적 수소 산화반 응을 통해 발전하는 $\mathrm{SOFC}$ 시스템의 개략도이다. 이 시 스템은 기존 $\mathrm{SOFC}$ 스택이나 시스템에 수소와 질소의 혼합가스를 공급하여 운전하는 조건과 매우 유사하기 때문에 암모니아에 의해 단전지나 스택의 구성 요소가 열화 될 가능성이 낮고 암모니아가 충분히 분해되지 않 아 낮은 연료 농도로 인한 성능 감소 또는 낮은 연료 이 용률로 인한 효율 감소 등의 문제를 예방할 수 있을 것 이다.

$$
\begin{aligned}
& \mathrm{NH}_{3} \rightarrow 0.5 \mathrm{~N}_{2}+1.5 \mathrm{H}_{2} \\
& \mathrm{H}_{2}+\mathrm{O}^{2-} \rightarrow \mathrm{H}_{2} \mathrm{O}+2 \mathrm{e}^{-}
\end{aligned}
$$

한편 암모니아 분해장치는 목적에 따라 시스템의 고 (a) SOFC with an external $\mathrm{NH}_{3}$ cracker

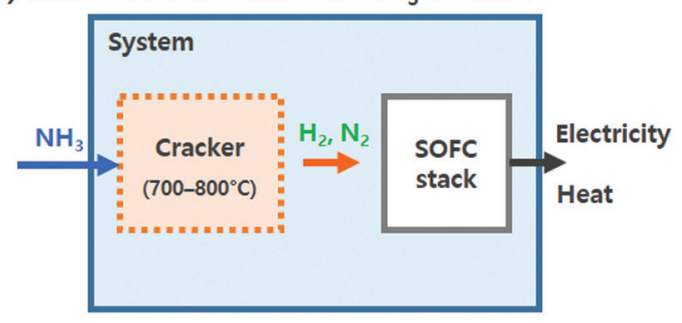

(b) SOFC with an autothermal $\mathrm{NH}_{3}$ cracker

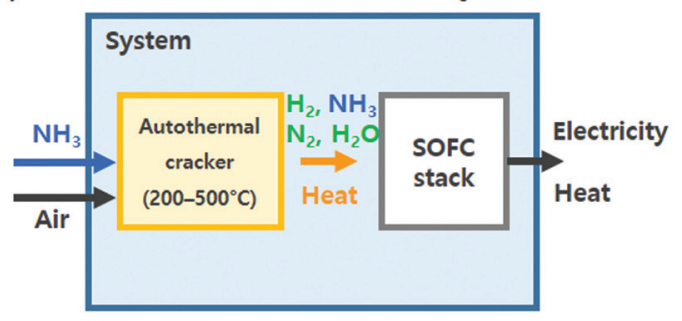

(c) Direct $\mathrm{NH}_{3}$ fueled SOFC

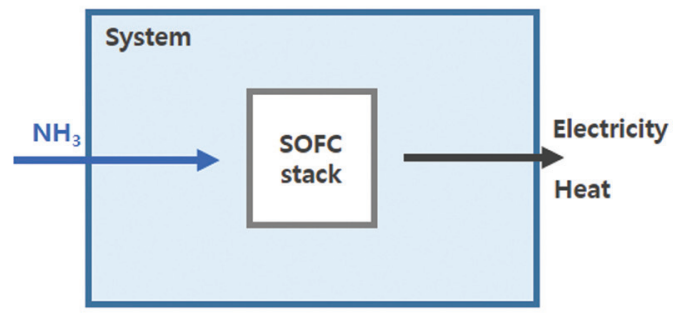

Fig.1. Schematic diagram of the ammonia fueled SOFC systems.

온부(hotbox) 외부에 별도로 배치하거나 $\mathrm{SOFC}$ 스택과 통합하여 내부에 배치하여 구성할 수 있다. 암모니아 분 해반응은 흡열반응 $\left(46 \mathrm{~kJ} / \mathrm{mol}, 25^{\circ} \mathrm{C}\right)$ 이므로 전자의 경 우 외부에 설치된 분해장치는 반응에 필요한 열을 외부 에서 별도로 공급받아 암모니아를 분해한 후 스택으로 공급할 수 있다. 따라서 단기적으로 상용 스택이나 시 스템에 연결하여 운전이 가능하므로 신속하게 암모니 아를 연료로 활용하는 SOFC 시스템 개발에 유리할 것 이다. 다만 암모니아 분해장치 추가에 따라 시스템 복 잡성이 증가하고 반응열을 공급하기 위한 추가적인 에 너지 소모가 예상되므로 전체 시스템 효율과 열 균형을 극대화하기 위한 기술 개발이 필요할 것이다. 또한 암 모니아 분해반응 속도는 작동 온도, 압력 및 촉매에 영 
향을 받으며, 분해장치에서 연료의 전환율(conversion rate)에 따라 스택이나 시스템의 성능과 효율이 좌우되 므로 가능한 낮은 온도에서 분해반응에 높은 활성을 갖 는 고내구성 촉매 개발이 필요하다. 분해장치를 $\mathrm{SOFC}$ 스택과 함께 고온부에 배치하여 운전할 경우에는 반응 열을 스택에서 직접 공급받을 수 있어 효율적인 열관리 가 가능하고 시스템 효율 향상에 긍정적일 것이다. ${ }^{[17]}$ Kishimoto 등은 전기로 내부에 상용 $\mathrm{SOFC}$ 스택과 분 해장치를 연계하여 설치한 후 암모니아를 연료로 사용 하여 $750^{\circ} \mathrm{C}$ 에서 약 $690 \mathrm{~W}$ 의 출력으로 1,000 시간까지 장기 안정성을 확인하였으며, 효율은 $56.2 \%$ 로 나타났 다. ${ }^{[19]}$ 다만 이러한 시스템은 고온부에 설치된 스택이나 열교환기, 후단연소기 같은 기존 구성요소들의 배치에 따라 분해장치의 사양이나 크기가 제한될 수 있으며 고 온부에 반응기를 별도로 추가할 경우에는 시스템 부피 가 증가될 수 있다. ${ }^{[18]}$

탄화수소계 연료를 사용하는 SOFC 시스템에서는 연 료에 일부 산소를 공급하여 발열반응인 촉매 부분 산화 (Catalytic Partial Oxidation : CPOx) 반응을 일으켜 부분 개질된 연료와 스택 작동에 필요한 열을 동시에 공 급하기도 한다. 암모니아 산화반응은 식 (3)과 같이 발 열반응 $\left(-317 \mathrm{~kJ} / \mathrm{mol}, 25^{\circ} \mathrm{C}\right)$ 이며, 흡열반응인 암모니아 분해반응을 고려하면 식 (4)와 같은 분해 반응에서 열 적 평형(thermoneutral)을 이루는 상태가 된다. 따라 서 $\mathrm{CPOx}$ 개질기와 유사하게 암모니아의 부분 산화반응 으로 생성된 열을 스택 기동과 분해반응에 공급하고 분 해된 수소를 연료로 이용할 수 있는 자열반응 분해장치 (autothermal cracker)를 고안하여 Fig. 1(b)와 같이 $\mathrm{SOFC}$ 스택과 연계한 시스템도 개발되고 있다. ${ }^{[19]}$

$$
\begin{gathered}
\mathrm{NH}_{3}+0.75 \mathrm{O}_{2} \rightarrow 0.5 \mathrm{~N}_{2}+1.5 \mathrm{H}_{2} \mathrm{O} \\
\mathrm{NH}_{3}+0.095 \mathrm{O}_{2} \rightarrow 0.5 \mathrm{~N}_{2}+1.31 \mathrm{H}_{2}+0.19 \mathrm{H}_{2} \mathrm{O} \text { 식 (3) }
\end{gathered}
$$

이 경우 스택 작동에 필요한 열과 연료의 공급이 동 시에 가능하기 때문에 외부 열원을 최소화하는 암모 니아 $\mathrm{SOFC}$ 시스템 제작에 용이하다. 다만 자열반 응 분해장치에 적합한 촉매 소재 개발과 반응열과 연
료의 동시 공급을 위한 공기 대 연료비(Air to Fuel Ratio: AFR)와 같은 최적 운전 조건 도출 및 이를 적 용한 효율적인 반응장치의 설계 및 제작이 필요할 것 이다. 선행연구에 따르면 $\mathrm{Co}-\mathrm{Ce}-\mathrm{Zr}$ 촉매를 벌집구 조의 세라믹 지지체에 코팅한 후 자열반응 분해장치 에 적용하여 $\mathrm{AFR} 0.75$ 인 조건에서 1,000 시간 동안 외 부 열 공급 없이 운전하면서 약 $80 \%$ 의 암모니아 전환 율이 안정적으로 유지되었다고 보고한 바 있다. ${ }^{[20]}$ 이 후 상용 SOFC 스택과 연계하여 AFR 조건을 0.450.75 로 변화시키면서 평가한 결과, 생성되는 혼합가 스 중 수증기나 질소의 농도가 변함에도 불구하고 모 든 조건에서 약 $900 \mathrm{~W}$ 의 유사한 최대출력을 나타 내었다, 따라서 암모니아 분해가스 중 수증기나 질 소의 농도가 성능에 큰 영향을 끼치지 않음을 알 수 있다. ${ }^{[19]}$

다음은 Fig. 1(c)와 같이 암모니아 연료를 분해장치를 거치지 않고 직접 연료극에 공급하여 작동하는 직접 암 모니아 연료용 SOFC(Direct Ammonia fueled-SOFC: $\mathrm{DA}-\mathrm{SOFC}$ ) 기술 개발에 관한 내용이다. $700^{\circ} \mathrm{C}$ 이상 의 고온에서 암모니아를 직접 연료로 사용하여 연료극 에 적용된 촉매에서 암모니아가 분해되고 생성된 수소 가 전기화학적으로 산화되어 전기를 생산한다. 따라서 앞서 소개한 경우들에 비해 시스템 단순화 및 효율 극대 화에 장점을 갖고 있으며, 해외 연구기관이나 기업들을 중심으로 상용 $\mathrm{SOFC}$ 소재, 단전지 및 스택 등을 암모니 아 연료로 평가하면서 $\mathrm{DA}-\mathrm{SOFC}$ 상용화에 필요한 핵 심 요소 기술 개발을 활발히 추진하고 있다.

$\mathrm{DA}-\mathrm{SOFC}$ 성능은 작동 온도, 연료 조성, 전해질과 전극 소재, 단전지 구조 및 제조 공정 등 다양한 변수 에 따라 달라진다. 특히 작동 온도는 소재와 단전지 구 조 선택에 주요한 요인이다. 전해질은 전극에 비해 전도 도가 낮기 때문에 내부저항을 최소화하여 고성능을 구 현하고자 이온전도도가 높은 소재나 얇은 전해질 층을 적용한 연료극 지지형 구조의 단전지를 주로 사용한다. $\mathrm{DA}-\mathrm{SOFC}$ 는 적용하는 전해질의 유형에 따라 Fig. 2 와 같이 산소 이온 $\left(\mathrm{O}^{2-}\right)$ 전도성 전해질 기반의 $\mathrm{SOFC}-\mathrm{O}$ 와 양성자 $\left(\mathrm{H}^{+}\right)$전도성 전해질 기반의 $\mathrm{SOFC}-\mathrm{H}$ 로 구분 


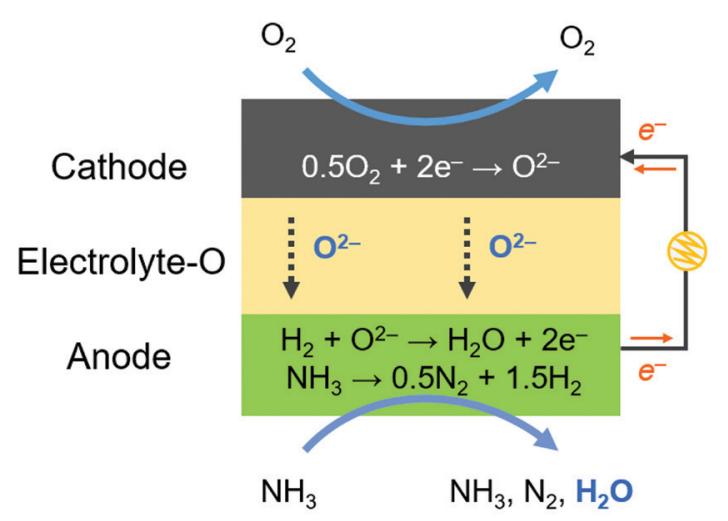

(a) Direct $\mathrm{NH}_{3}$ fueled SOFC-O

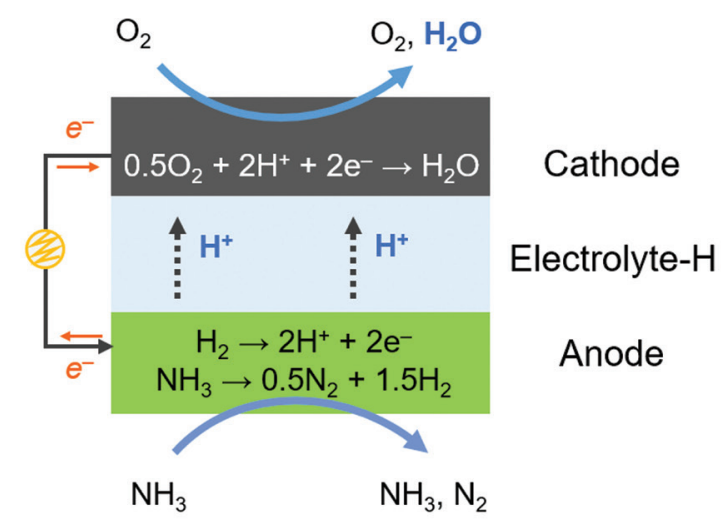

(b) Direct $\mathrm{NH}_{3}$ fueled SOFC-H

Fig. 2. Schematic diagram of the working principles of the direct ammonia fueled SOFCs using (a) an oxide ion conducting (SOFC-O) or (b) a proton conducting ceramic electrolyte (SOFC-H).

할 수 있다. ${ }^{[21]} \mathrm{SOFC}-\mathrm{O}$ 는 암모니아 연료가 연료극으 로 공급되어 분해되고, 공기극으로 공급되는 공기 중 산 소는 산소 이온으로 환원되어 전해질을 통해 연료극으 로 확산하여 이동한다. 이후 산소 이온은 연료극과 전해 질 사이의 삼상계면(triple phase boundary)에서 수소 와 전기화학반응을 일으켜 수증기와 전자를 생성하고, 전자들은 외부 회로를 통해 공기극으로 이동한다. ${ }^{[22]}$ 대 표적인 산소 이온 전도성 전해질 소재로는 $\mathrm{YSZ}\left(\mathrm{Y}_{2} \mathrm{O}_{3}-\right.$ stabilized $\left.\mathrm{ZrO}_{2}\right), \operatorname{SDC}\left(\mathrm{Sm}_{2} \mathrm{O}_{3}\right.$-doped $\left.\mathrm{CeO}_{2}\right)$, GDC $\left(\mathrm{Gd}_{2} \mathrm{O}_{3}\right.$-doped $\left.\mathrm{CeO}_{2}\right), \mathrm{ScCeSZ}\left(\mathrm{Sc}_{2} \mathrm{O}_{3} \& \mathrm{CeO}_{2}-\right.$ stabilized $\left.\mathrm{ZrO}_{2}\right), \mathrm{ESB}\left(\mathrm{Er}_{2} \mathrm{O}_{3}\right.$-stabilized $\left.\mathrm{Bi}_{2} \mathrm{O}_{3}\right)$ 및 $\mathrm{LSGM}\left(\mathrm{Sr}\right.$ and $\mathrm{Mg}$-doped $\mathrm{LaGaO}_{3}$ ) 등이 보고되고 있 다. ${ }^{[4]}$ 반면 $\mathrm{SOFC}-\mathrm{H}$ 는 암모니아가 연료극에서 분해된 후 생성된 수소가 양성자로 산화되어 양성자 전도성 전 해질을 통해 공기극으로 이동한 후 전해질과 인접한 삼 상계면에서 산소와 반응하여 수증기를 형성한다. 따라서 $\mathrm{SOFC}-\mathrm{O}$ 에서와 같이 연료극에서 생성된 수증기에 의해 연료가 희석되어 수소 농도가 감소하지 않기 때문에 연 료이용률이 동일할 경우 $\mathrm{SOFC}-\mathrm{H}$ 의 효율이 $\mathrm{SOFC}-\mathrm{O}$ 에 비해 약 $10 \%$ 높게 나타난다. 대표적인 양성자 전도 성 전해질은 $\mathrm{BCY}\left(\mathrm{BaCe}_{1-\mathrm{x}} \mathrm{Y}_{\mathrm{x}} \mathrm{O}_{3-\delta}\right), \mathrm{BZY}\left(\mathrm{BaZr}_{1-\mathrm{x}} \mathrm{Y}_{\mathrm{x}} \mathrm{O}_{3-\delta}\right)$, $\mathrm{BCZY}\left(\mathrm{BaCe}_{1-\mathrm{x}-\mathrm{y}} \mathrm{Zr}_{\mathrm{x}} \mathrm{Y}_{\mathrm{y}} \mathrm{O}_{3-\delta}\right), \mathrm{BCG}\left(\mathrm{BaCe}_{1-\mathrm{x}} \mathrm{Gd}_{\mathrm{x}} \mathrm{O}_{3-\delta}\right)$ 등 이 보고되었다. ${ }^{[3,22]}$ 특히 양성자 전도성 전해질은 600
${ }^{\circ} \mathrm{C}$ 이하에서 산소 이온 전도성 전해질에 비해 전도도 가 높기 때문에 수소 연료를 이용할 경우 보다 높은 성 능을 구현할 수 있다. 하지만 암모니아 연료를 사용할 경우 암모니아 분해반응이 급격히 감소하여 출력이 낮 아질 수 있기 때문에 중 - 저온 $\left(400-600^{\circ} \mathrm{C}\right)$ 에서도 촉 매 및 전기화학적 반응 특성이 우수한 연료극 소재 개발 이 필수적이다. 또한 뒷부분에서 설명하겠지만 작동온 도가 감소함에 따라 암모니아 분위기에서 단전지 소재 나 부품의 질화(nitriding) 문제가 촉진될 수 있기 때문 에 이에 대한 문제 해결도 고려해야 할 것이다. 무엇보 다 양성자 전도성 소재들은 대체로 낮은 소결성과 $\mathrm{CO}_{2}$ 나 수증기 분위기에서의 화학적 불안정성 등과 같은 문 제 해결이 시급하며, 단전지 대면적화 또는 $\mathrm{kW}$ 급 스택 기술 개발 같은 양산화에 필요한 한계를 우선적으로 극 복해야 할 것이다. 따라서 현 시점에서는 암모니아 연료 용 $\mathrm{SOFC}$ 의 양산화를 위해서 $700^{\circ} \mathrm{C}$ 이상에서 작동하는 $\mathrm{SOFC}-\mathrm{O}$ 가 적합할 것으로 예상되므로 이후에는 이를 중심으로 한 $\mathrm{DA}-\mathrm{SOFC}$ 기술 개발 현황과 문제점들을 살펴보고 개선 방안에 대해 논의할 것이다.

\section{3. 직접 암모니아 연료용 SOFC 개발 현황}

$\mathrm{DA}-\mathrm{SOFC}$ 의 연료극은 촉매를 통해 암모니아를 완전 
히 분해하여 수소를 원활히 생산하면서 높은 성능을 구 현하기 위해 수소 산화반응에 대한 전기화학적 특성도 충분히 활성화되어야 한다. 구조적으로는 연료 가스가 반응 활성화 영역으로 확산되고 반응 생성물이 활성화 영역으로부터 효과적으로 배출, 제거될 수 있도록 충분 한 기공률을 가져야 하며 전자전도성이 높아야 한다. 또 한, 고온의 암모니아 분위기에서 미세구조나 촉매 및 전 기화학적 특성이 안정해야 하며, 경제적인 관점에서 값 비싼 귀금속 촉매대신 저렴한 소재를 이용하여 제작이 간편하고 내구성이 충분히 높아야 한다. 따라서 암모니 아를 $\mathrm{SOFC}$ 의 연료로 직접 사용하기 위해서는 연료극의 성능과 내구성을 확보해야 하므로 소재 선택이 매우 제 한적이다. ${ }^{[3,24,25]}$

암모니아의 분해는 식 (5)-(10)과 같이 단계적인 탈수 소화 반응을 통해 발생하는데, 크게 다음의 세 가지 과 정: (1) 촉매 활성화 부위(*)에 암모니아의 흡착(식 (5)), (2) 수소 원자를 방출하기 위해 흡착된 암모니아에서 $\mathrm{N}-\mathrm{H}$ 결합의 연속적인 분리(cleavage)(식 (6)-(8)) 및 (3) 질소와 수소 원자들의 재결합 후 질소 및 수소 가스 로의 탈착(식 (9)-(10))을 거치게 된다.

$$
\begin{gathered}
\mathrm{NH}_{3}+{ }^{*} \rightarrow \mathrm{NH}_{3}{ }^{*} \\
\mathrm{NH}_{3}{ }^{*}+{ }^{*} \rightarrow \mathrm{NH}_{2}{ }^{*}+\mathrm{H}^{*} \\
\mathrm{NH}_{2}{ }^{*}+{ }^{*} \rightarrow \mathrm{NH}^{*}+\mathrm{H}^{*} \\
\mathrm{NH}^{*}+{ }^{*} \rightarrow \mathrm{N}^{*}+\mathrm{H}^{*} \\
\mathrm{~N}^{*}+\mathrm{N}^{*} \rightarrow \mathrm{N}_{2} \\
\mathrm{H}^{*}+\mathrm{H}^{*} \rightarrow \mathrm{H}_{2}
\end{gathered}
$$

따라서 최적의 분해 촉매는 암모니아에 대해 충분히 강한 결합 에너지를 가져야 촉매의 활성 부위에 흡착되 어 단계적으로 탈수소화 될 수 있는 반면, 질소원자와 수소원자가 각각 재결합을 통해 질소와 수소 분자로 쉽 게 탈착될 수 있도록 원자와의 결합력은 약해야 한다. 문헌에 따르면 암모니아 분해반응에 대한 다양한 촉매 금속의 활성은 다음과 같이 $\mathrm{Ru}>\mathrm{Ni}>\mathrm{Rh}>\mathrm{Co}>\mathrm{Ir}>$ $\mathrm{Fe}$ 순서를 따른다고 한다. ${ }^{[26]}$ 하지만 $\mathrm{Ru}$ 촉매 소재는 비 용이 높고 전 세계적으로 생산량이 매우 제한적이기 때
문에 Ni과 같이 경제성과 촉매 활성이 우수한 대체 촉매 의 개발이 활발히 진행되고 있다. 다행스럽게도 $\mathrm{Ni}$ 은 상 용 SOFC 연료극에 가장 널리 사용되고 있는 촉매 소재 이며 고온 작동으로 촉매 활성도 높아 $\mathrm{Ru}$ 과 같은 귀금 속 촉매를 대신할 수 있을 것이다.

대표적인 SOFC-O 연료극 소재인 Ni-YSZ는 수소 나 탄화수소 기반 연료뿐만 아니라 직접 암모니아 연 료에서도 분해반응에 대한 촉매 특성과 전기화학적 반 응성 및 장기 안정성을 갖는 것으로 보고되었다. ${ }^{[27-34]}$ Hagen 등은 Ni-YSZ 연료극을 적용한 단전지를 이용하여 $850^{\circ} \mathrm{C}$ 에서 암모니아를 직접 연료로 공급하여 분해특 성과 단전지 성능 및 내구성을 수소와 질소의 혼합가스 $\left(\mathrm{H}_{2}: \mathrm{N}_{2}=3: 1\right)$ 연료와 비교하여 평가하였다. 연료극 배출 구에 연결된 질량분석기를 통해 배가스를 분석하여 암 모니아 분해반응을 관찰했을 때 혼합가스를 공급한 경 우와 수소와 질소의 신호 강도가 거의 동일하게 나타났 으며 잔류 암모니아 성분은 확인되지 않은 반면 연료극 에 공급되기 직전의 가스를 분석했을 때는 암모니아가 검출되었다. 따라서 공급된 암모니아가 Ni-YSZ 연료 극에서 완전히 분해되었음을 확인할 수 있었다. 추가적 으로 배가스 분석 결과에 따르면 $\mathrm{NO}, \mathrm{NO}_{2}$ 또는 $\mathrm{N}_{2} \mathrm{O}$ 와 같은 독성가스 성분은 검출되지 않았다. 또한 단전지 성 능 평가 결과 암모니아 연료를 공급한 경우 혼합가스 연 료의 경우와 비슷한 출력밀도를 나타내었다. 1,500 시간 내구성 평가에서도 초기 500시간 동안은 혼합가스 연료 에 비해 다소 높은 성능 감소율을 나타내었지만 이후에 는 동등한 수준의 안정성을 유지하였다. ${ }^{[30]}$ 따라서 암모 니아 연료를 상용 Ni-YSZ 연료극에 직접 사용할 수 있 음을 확인하였는데, 이는 암모니아가 완전히 분해될 수 있도록 작동 온도가 충분히 높았기 때문으로 사료된다. 반면 Shy 등은 Ni-YSZ 연료극을 사용한 단전지에 대 해 수소와 암모니아를 각각 연료로 활용하여 성능을 측 정하였는데, $850^{\circ} \mathrm{C}$ 에서 최대 출력밀도는 수소와 암모니 아에 대해 $1,192 \mathrm{~mW} / \mathrm{cm}^{2}$ 와 $1,174 \mathrm{~mW} / \mathrm{cm}^{2}$ 로 약 $1.5 \%$ 성능 차이가 나타났으나 $750^{\circ} \mathrm{C}$ 에서는 $1,078 \mathrm{~mW} / \mathrm{cm}^{2}$ 와 $950 \mathrm{~mW} / \mathrm{cm}^{2}$ 로 약 $11.9 \%$ 차이가 발생하여 작동 온 도가 감소함에 따라 암모니아 연료에서 성능이 현저히 


\section{특 집 ㅍ 홍종은, 이승복, 조동우, 김혜성, 임탁형, 박석주, 송락현}

감소하였다. ${ }^{[31]}$ 이는 작동 온도 감소에 따라 연료극에서 암모니아 전환율이 감소했기 때문으로 판단되며, 낮은 작동온도에서도 동등한 성능을 구현하기 위해서는 효과 적인 연료극 촉매 소재 개발이 필수적임을 예상할 수 있 다. 한편 Kishimoto 등은 $1 \mathrm{~kW}$ 급 상용 $\mathrm{SOFC}$ 스택에 암모니아 연료를 직접 공급하여 초기 성능과 장기 내구 성을 평가하였다. $750^{\circ} \mathrm{C}, 50 \mathrm{~A}$ 인가전류와 연료이용률 $85 \%$ 조건에서 $1 \mathrm{~kW}$ 이상의 출력을 확보하였으나, 혼합 가스 $\left(\mathrm{H}_{2}: \mathrm{N}_{2}=3: 1\right)$ 연료에 비해서는 약간의 성능 감소가 확인되었다. 내구성 평가에서는 초기 200시간 동안에는 스택이 활성화되어 전압이 점점 증가하다가 이후에 안 정화되어 1,000시간까지 $55.9 \%$ 효율로 약 $690 \mathrm{~W}$ 의 일 정한 출력을 나타내었으며, 이전 결과보다 ${ }^{[20]}$ 향상된 내 구성을 확보하여 $\mathrm{DA}-\mathrm{SOFC}$ 시스템의 상용화 가능성을 확인할 수 있었다. 한편 혼합가스 연료 대비 성능 감소 원인은 암모니아 연료 공급에 따라 흡열반응인 암모니 아 분해반응이 연료극에서 발생하면서 단전지의 실질적 인 작동 온도가 감소했기 때문이라고 설명하였으며, 스 택의 온도를 실제 측정한 결과에서도 연료 도입부 근처 의 온도가 약 $15^{\circ} \mathrm{C}$ 까지 감소한 것으로 나타났다. ${ }^{[19]}$ 이와 유사하게 단전지나 스택에 암모니아 연료를 직접 공급 하였을 때 연료 도입부에서 유로 중간영역이나 배출구 보다 온도가 감소하는 결과가 관찰된 바 있다. ${ }^{[32]}$

Stoeckl 등은 Ni-YSZ 연료극을 적용한 평판형 단전 지(유효전극면적 $\left.=80 \mathrm{~cm}^{2}\right)$ 를 이용하여 Fig. 3(a)와 같이 연료극 유로 내 다양한 위치에서 혼합가스와 암모니아 를 각각 연료로 공급했을 때 측정되는 온도의 차이를 분 석하고 암모니아의 유량이나 질소 희석, 가스공급 방식 등에 따른 암모니아 전환율이나 단전지 성능 변화 등을 $700^{\circ} \mathrm{C}$ 와 $800^{\circ} \mathrm{C}$ 에서 평가하였다. ${ }^{[32]}$ 우선 혼합가스 연료 를 공급한 경우보다 암모니아를 공급하였을 때 전체적 으로 유로 내부에서 온도가 다소 낮게 측정되었다. Fig. 3(b)에서 연료 가스에 따른 유로의 위치별 온도차를 살 펴보면 매니폴드의 입구 부근(T1)에서 $25^{\circ} \mathrm{C}$ 정도로 가 장 높은 차이를 나타내며 출구 방향으로 갈수록 온도차 가 점차 감소하였다. 이를 통해 암모니아가 입구 부근 의 연료극에서 활발히 분해되면서 흡열반응에 의해 급 (a)

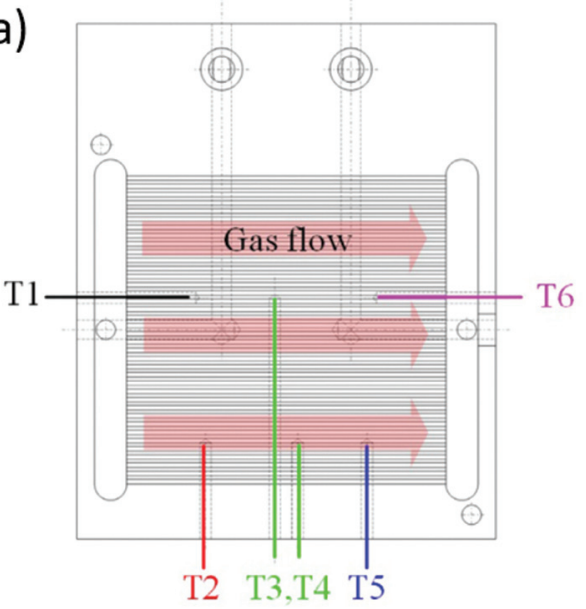

(b)

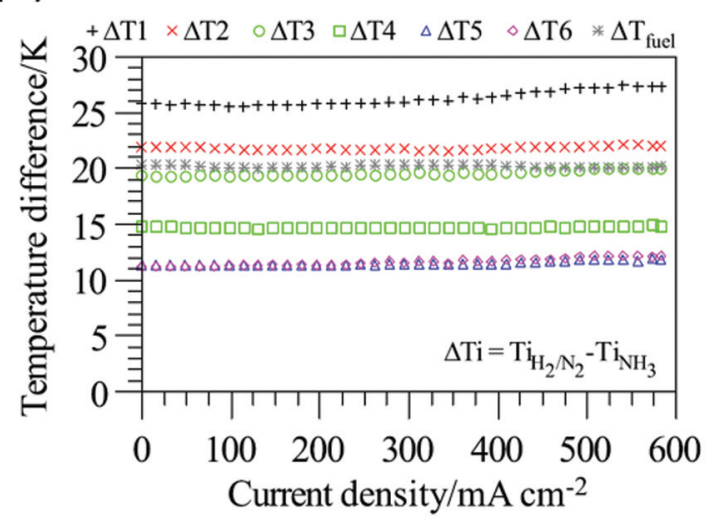

(c)

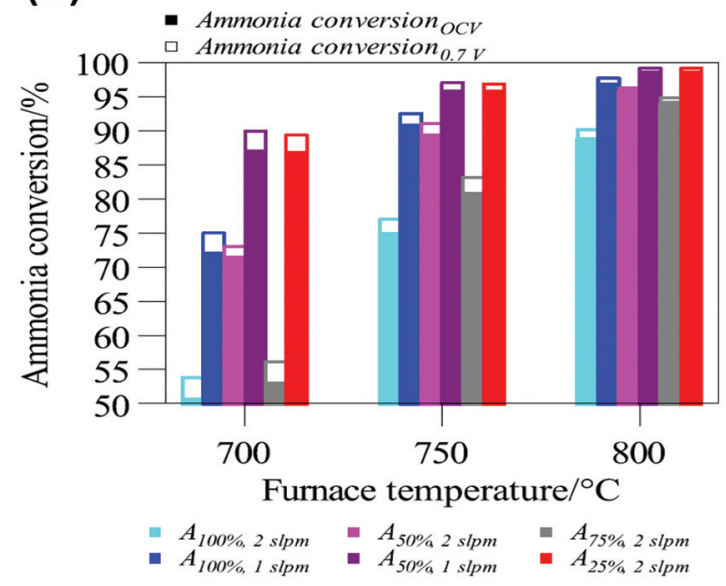

Fig. 3. (a) The ceramic bottom flow field, (b) temperature analysis of the operation with $\mathrm{A}_{100 \%, 1 \mathrm{slpm}}\left(\mathrm{NH}_{3}\right.$ 100\%) and $\mathrm{H}_{75 \%, 2 \text { sipm }}\left(\mathrm{H}_{2} 75 \%, \mathrm{~N}_{2} 25 \%\right)$ at $750^{\circ} \mathrm{C}$, and (c) comparison of the ammonia conversion rates with different fuel compositions. Reproduced from Stoeckl et al. Electrochim. Acta., 2019;298:874-883, with permission of Elsevier [32]. 
격한 온도변화가 발생하였음을 추측해 볼 수 있다. 또 한 유량 증가에 따라 암모니아 전환율도 낮아졌는데 유 로 내에서 반응가스의 공간속도(space velocity)가 빨라 져 체류시간(residence time)이 짧아지면서 암모니아와 촉매 간 접촉이 상대적으로 감소하였기 때문이다(Fig. $3(\mathrm{c})$ ). 한편 동일 유량의 암모니아에 질소를 추가하여 희 석시킨 경우 질소 유량 증가에 따른 암모니아 전환율은 큰 변화가 없었다. 수증기의 조성 또한 암모니아 전환율 과 상관관계가 거의 없다고 보고된 반면 수소 농도 증가 는 암모니아 전환율을 감소시키며 온도 저하에 따라 더 심하게 발생하는 수소 피독 $\left(\mathrm{H}_{2}\right.$ poisoning $)$ 현상이 보고 되었다. ${ }^{[29,30]}$ 이는 분해된 수소원자가 $\mathrm{Ni}$ 촉매의 활성화 부위를 차지하여 분해반응을 저해하기 때문인데 온도 가 충분히 높아지면 수소가 원활히 탈착되어 피독이 감 소하게 될 것이다. ${ }^{[29]}$ 단전지 성능에서는 암모니아 유량 이 증가함에 따라 연료극의 온도가 더 감소하여 단전지 의 오믹저항 증가로 인해 출력이 감소하였다. 한편 일정 한 전류밀도를 인가하면서 24 시간 동안 단전지 전압과 암모니아 전환율을 측정하였는데 $800^{\circ} \mathrm{C}$ 에서는 두 인자 모두 점차 증가하여 성능과 분해특성이 향상되는 것으 로 나타났다. 하지만 $700^{\circ} \mathrm{C}$ 에서는 전압과 전환율 거동 이 다르게 나타났다. 전압은 점차 감소하여 $2 \%$ 정도 낮 아졌으나 전환율은 오히려 점차 증가하는 것으로 나타 났다(Fig. 4(a)). 특히 $700^{\circ} \mathrm{C}$ 에서의 성능 열화율은 동일 온도에서 수소 연료를 공급한 단전지의 열화율에 비해 현저히 높았으며, 임피던스 분석 결과에 따르면 오믹저 항과 분극저항 모두 증가하였고, 분극저항에서는 특히 가스확산과 연관된 저주파수 영역에서의 증가가 두드러 졌다(Fig. 4(b)). 연료극에 대한 사후분석에 따르면 특 히 $\mathrm{Ni}$ 입자의 급격한 미세구조 변화가 관찰되었는데, 이 는 질화에 의한 현상으로 입자들이 조대해졌지만 표면 에 미세한 기공들이 생성되어 상대적으로 표면적이 증 가하면서 암모니아 전환율이 점차 향상되었다고 설명하 였다. ${ }^{[32]}$ 하지만 이러한 질화 문제는 $800^{\circ} \mathrm{C}$ 보다 $700^{\circ} \mathrm{C}$ 에서 보다 급격하게 발생하면서 임피던스 분석결과에서 확인된 바와 같이 점차 접촉저항을 증가시키거나 입성 장으로 인해 반응가스의 확산을 방해하면서 분극저항을
증가시켜 단전지 성능을 감소시킨 것으로 사료된다. 즉 $\mathrm{DA}-\mathrm{SOFC}$ 의 경우 작동온도가 감소함에 따라 성능 열 화가 가속화됨을 확인할 수 있었으며, 상용화를 위해서 는 암모니아 전환율이 높고 장기 안정성이 우수한 연료 극 촉매 소재 개발이 중요할 것이다.

암모니아 분해반응에서 촉매 활성은 일반적으로 촉매 의 단위 부피당 활성 부위(active site)의 수에 의존하므 로 표면적이 큰 지지체를 사용하여 미세한 금속 촉매 입 자를 고르게 분산시켜 암모니아에 노출될 수 있는 활성 화 부위를 극대화해야 한다. 또한 지지체를 도입하면 촉 매가 우수한 기계적, 화학적 강도를 얻어 안정성을 향 상시킬 수 있기 때문에 최적의 촉매를 개발하기 위해서 는 촉매 제조 방법과 함께 최적의 지지체에 대한 신중 한 선택이 필요하다. 실제로, 지지체는 활성 촉매를 고 도로 분산시킬 뿐만 아니라 형성된 촉매 입자의 크기 및 형태와 미세구조 특성을 결정하는 데 중요한 역할을 한다. ${ }^{[35,36]}$ 또한 지지체의 전자전도성은 촉매 입자로부 터 질소의 탈착을 촉진하여 분해반응속도를 향상시키는 데 효과적인 것으로 확인되었으며, 지지체에 분산된 촉 매 입자에 전자 공여 특성을 가진 첨가제를 추가하여 촉 매 활성을 더욱 향상시킬 수 있었다. ${ }^{[37-39]}$ 즉, 촉매에 첨 가된 물질이 지지체와 촉매에 전자를 공여하여 활성 부 위에 전자적 변형(electronic modification)을 유발하 여 분해반응의 활성화에너지를 감소시키는 것으로 추측 된다. ${ }^{[38,39]}$ Okanish 등은 $\mathrm{Ni}-\mathrm{Y}_{2} \mathrm{O}_{3}$ 기반의 촉매를 이용 하여 암모니아 분해 반응 특성을 평가하였는데 $\mathrm{SrO}$ 첨 가로 촉매 표면의 염기성을 증가시켜 촉매 활성을 향 상시킬 수 있었다. 또한 $700^{\circ} \mathrm{C}$ 의 암모니아 분위기에서 1,000 시간 동안 안정한 분해 특성을 확인하였으나 반 응온도가 $550^{\circ} \mathrm{C}$ 이하로 감소함에 따라 촉매 활성이 급 격히 낮아졌다. ${ }^{[20]}$ 문헌에 따르면 $\mathrm{Ru}$ 촉매에 alkali 또 는 alkali-earth 금속 같은 강염기성 원소를 첨가한 경 우 암모니아 분해반응이 향상되었으며, 이는 염기성 첨 가제를 통해 전자 공여가 원활해져 질소의 탈착이 촉진 되었기 때문이라고 설명하였다. ${ }^{[17-21,23-25]}$ 또한 희토류 (rare-earth) 산화물을 $\mathrm{Ni}$ 촉매에 첨가한 경우에도 분 해반응이 개선되었는데, 촉매와 첨가제 간의 상호작용 

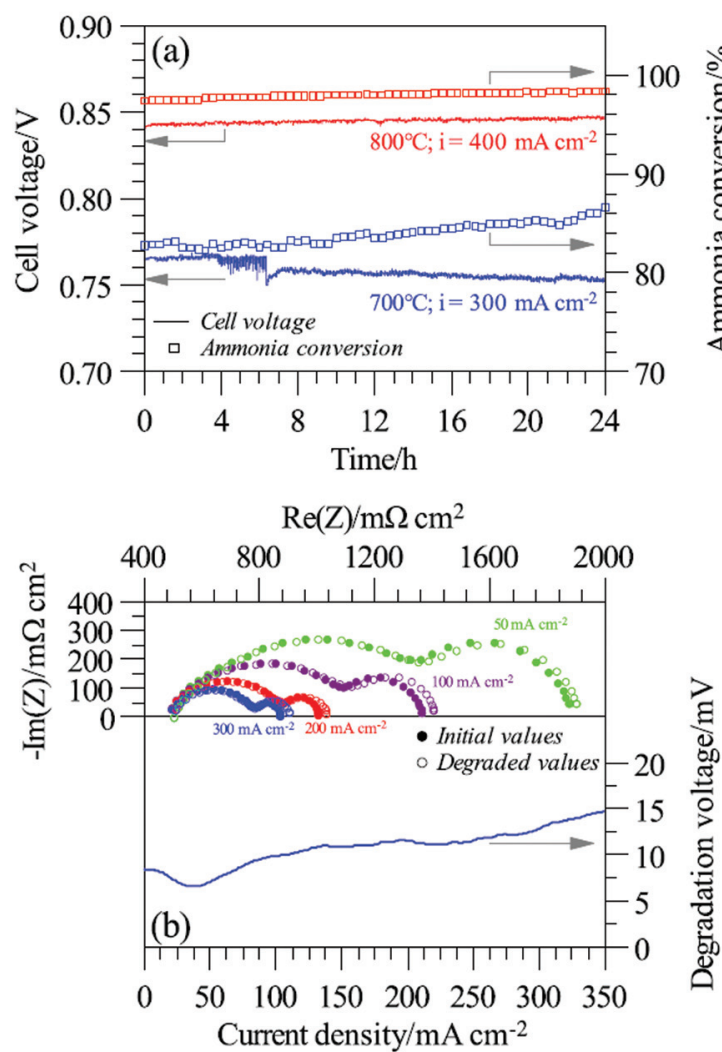

Fig. 4. (a) $24 \mathrm{~h}$ tests at $700^{\circ} \mathrm{C}, 300 \mathrm{~mA} / \mathrm{cm}^{2}$ and $800^{\circ} \mathrm{C}, 400$ $\mathrm{mA} / \mathrm{cm}^{2}$ with $\mathrm{A}_{50 \%, 2}$ sipm $\left(50 \% \mathrm{NH}_{3}-50 \% \mathrm{~N}_{2}\right)$ : the cell voltage and $\mathrm{NH}_{3}$ conversion rate over time and (b) EIS measurements and the degradation voltage with current density at $700^{\circ} \mathrm{C}$. Adapted from Stoeckl et al. Electrochim. Acta., 2019;298:874-883, with permission of Elsevier [32].

이나 첨가된 입자에 의한 촉매의 분산 효과로 인해 반 응이 향상된 것으로 보고하였다. ${ }^{[37-39,42]}$ 따라서 낮은 온 도에서도 암모니아 분해반응 촉진하기 위해 $\mathrm{SrO}$ 대신 $\mathrm{BaO}$ 를 $\mathrm{Ni}$ 촉매에 첨가하고 $\mathrm{Sm}_{2} \mathrm{O}_{3}$ 와 $\mathrm{MgO}$ 산화물 지 지체에 담지한 경우 $515^{\circ} \mathrm{C}$ 에서도 $90 \%$ 이상의 전환율을 나타내었는데, $\mathrm{SrO}$ 보다 강한 염기성을 갖는 $\mathrm{BaO}$ 와 희 토류 산화물 첨가로 분해반응이 촉진되었다고 설명하 였다. ${ }^{[19]}$ 또한 Ni-YSZ 대신 Ni-GDC 연료극을 사용한 경우 보다 높은 암모니아 전환율을 나타내었다. GDC 와 YSZ에 대해 $\mathrm{CO}_{2}-\mathrm{TPD}$ (Temperature Programmed Desorption)를 측정한 결과 GDC가 YSZ에 비해 9배 이 상 높은 $\mathrm{CO}_{2}$ 탈착률을 나타내어, $\mathrm{GDC}$ 표면이 보다 염
기성 상태였는데, 이에 따라 YSZ는 암모니아 분해반응 에 거의 무관한 반면 $\mathrm{GDC}$ 는 암모니아 분해반응에 대 해 일부 촉매 특성을 나타내었다. 그 결과 $\mathrm{Ni}$ 촉매와 복 합전극을 이루었을 때 $\mathrm{Ni}$ 과 $\mathrm{GDC}$ 간의 화학적 상호작용 에 의해 $\mathrm{Ni}-\mathrm{YSZ}$ 보다 분해반응을 촉진하는 것으로 나 타났다. ${ }^{[25]}$ 한편 Meng 등은 ${ }^{[40]} \mathrm{Ni}-\mathrm{YSZ}$ 대신 $\mathrm{Ni}-\mathrm{SDC}$ 연료극과 $\mathrm{SDC}$ 전해질 및 $\mathrm{BSCF}(\mathrm{Sr}$ and $\mathrm{Fe}$-doped $\left.\mathrm{BaCoO}_{3}\right)$ 공기극을 적용한 단전지에 대해 직접 암모니 아 연료로 $650^{\circ} \mathrm{C}$ 에서 $1,190 \mathrm{~mW} / \mathrm{cm}^{2}$ 의 높은 출력밀도 를 얻었다. Ni-GDC와 유사하게 $\mathrm{Ni}-\mathrm{SDC}$ 연료극도 높 은 암모니아 전환율을 나타내었을 것으로 추정되며, 세 리아계 전해질은 낮은 산소분압에서 $\mathrm{Ce}^{4+}$ 이온이 $\mathrm{Ce}^{3+}$ 로 환원되면서 전하보상을 위해 전자전도성을 띄게 되는데 이에 따라 전자의 공여가 촉진되어 분해반응을 향상시 켰을 수도 있다. 이로 인해 낮아진 온도에서도 분해반응 이 활발해지고 수소 연료가 충분히 공급되어 높은 성능 을 나타낸 것으로 사료된다. 더불어 $\mathrm{SDC}$ 전해질이 $\mathrm{YSZ}$ 에 비해 이온전도도가 높아 오믹저항이 감소할 수 있고 중저온에서 산소 환원반응이 뛰어난 $\mathrm{BSCF}$ 공기극을 적 용함에 따라 분극저항을 감소시켜 출력밀도 향상에 기 여했을 수 있다. 한편 암모니아 분해반응 특성이 우수한 촉매 소재를 연료극 자체로 활용하는 방법 외에 기존 연 료극 표면에 촉매를 코팅하여 적용하는 방안도 고려해 볼 수 있다. 이 경우 연료극과 촉매층 간에 화학적 안정 성이 확보되어야 하며 열팽창계수 차이로 인한 박리 문 제를 최소화해야 할 것이다. 그러므로 연료극 촉매와 전 해질, 공기극 같은 소재의 선택과 단전지 제조 공정도 $\mathrm{DA}-\mathrm{SOFC}$ 성능에 중요한 인자이다.

암모니아 분해 성능은 촉매 입자의 크기와 형태 변화 에 따라 달라진다고 한다. ${ }^{[41,42]} \mathrm{Ni}$ 기반 촉매의 경우 최 적의 입자 크기는 약 $2.3 \mathrm{~nm}$ 로 보고되었으며, ${ }^{[35]} \mathrm{Ni}$ 클 러스터의 크기는 촉매 활성을 결정하는데 지배적이며, 촉매 제조 방법, 금속 전구체, 지지체 유형 및 소성 및 환원과 같은 열처리에 따라 조정할 수 있다. ${ }^{[35,43-46]}$ 하 지만 $700{ }^{\circ} \mathrm{C}$ 이상의 고온에서 금속의 나노 입자는 표면 적을 최소화하기 위해 급격한 입자성장을 통해 조대해 질 수 있어 시간에 따라 촉매 성능이 급격히 감소할 수 
있을 것이다. 따라서 나노 크기의 $\mathrm{Ni}$ 입자를 고온에서 도 안정하게 유지하면서 단위부피당 입자수를 극대화 할 수 있다면 암모니아 분해반응을 촉진하면서 내구성 을 확보할 수 있을 것이다. 최근에는 페로브스카이트나 이중층 구조의 페로브스카이트 산화물 지지체를 이용하 여 용출(ex-solution)법으로 나노 크기의 전이금속 (예: $\mathrm{Ni}, \mathrm{Fe}, \mathrm{Co}, \mathrm{Cu}, \mathrm{Pt}, \mathrm{Ag}$ 등) 촉매를 지지체 표면에 선 택적으로 형성시켜 $\mathrm{SOFC}$ 의 연료극으로 적용하는 연구 들이 활발하게 진행되고 있으며 단일 금속뿐만 아니라 이종 금속의 용출이나 용출된 이종 금속 간 세밀한 조성 제어도 가능한 것으로 보고되고 있다. ${ }^{[47,48]}$ 환원 열처리 를 통해 만들어진 용출 금속 입자들은 지지체 표면의 격 자와 부분적으로 결합되어 있어 고온에서도 입자성장이 효과적으로 억제되고 촉매 반응에 적합한 소재를 용출 시킴으로써 반응을 촉진시킬 수 있는 장점이 있다. 또한 페로브스카이트 산화물은 고온 환원분위기에서 혼합전 도성을 나타내므로 전자의 공여를 통해 촉매의 활성을 보다 촉진할 수 있을 것이다. 따라서 이러한 전도성 산 화물 지지체에 나노 용출입자를 형성시킨 소재를 DA$\mathrm{SOFC}$ 연료극에 적용할 수 있다면 암모니아 분해반응과 전기화학적 수소 산화반응을 동시에 향상시켜 높은 성 능과 내구성을 확보할 수 있을 것으로 예상된다.

\section{4. 직접 암모니아 연료용 SOFC의 문제점}

$\mathrm{DA}-\mathrm{SOFC}$ 의 내구성 평가 결과들에 따르면 연료극에 서 수소나 탄화수소계 연료를 사용하는 경우에 비해 다 른 형태의 열화거동을 나타난다고 보고되고 있다. ${ }^{[19,32]}$ 탄화수소계 연료를 사용하는 연료극은 탄소침적에 의해 급격한 성능 열화가 발생하는 반면, 암모니아 연료에서 는 연료극의 $\mathrm{Ni}$ 촉매에서 질화로 인한 미세 구조 변화가 열화의 주요 원인으로 보고되었다. ${ }^{[29]} \mathrm{Ni}$ 기반의 연료극 에서 암모니아의 분해반응과 전기화학적 산화반응에는 $\mathrm{Ni}$ 입자가 중추적인 역할을 수행하는데, 암모니아 분해 시 단계적인 탈수소화 반응과 더불어 질화 반응도 발생 할 수 있어 식 (11)과 같이 $\mathrm{Ni}$ 질화물이 형성된다. ${ }^{[19]}$

$$
6 \mathrm{Ni}+2 \mathrm{NH}_{3} \rightarrow 2 \mathrm{Ni}_{3} \mathrm{~N}+3 \mathrm{H}_{2}
$$

형성된 $\mathrm{Ni}$ 질화물은 촉매 소재나 운전 조건에 따라 안 정하게 유지될 수 있다. $\mathrm{Ni}-\mathrm{N}$ 상태도에 따르면 $600^{\circ} \mathrm{C}$ 이하의 순수 암모니아 분위기에서는 $\mathrm{Ni}_{3} \mathrm{~N}$ 이 안정한 것 으로 나타났으며, ${ }^{[49]} \mathrm{DA}-\mathrm{SOFC}$ 평가를 마친 연료극 표 면에서도 실험적으로 확인된 바 있다. ${ }^{[19,27,32]} \mathrm{Yang}^{[27]}$ 등 은 DA-SOFC에서 Ni-YSZ 연료극의 안정성을 평가한 후 $\mathrm{EDS}$ 분석을 통해 $\mathrm{Ni}$ 입자 표면에 질소 원소가 존재 함을 확인하였으며, $700^{\circ} \mathrm{C}$ 에서 평가한 시료보다 $600^{\circ} \mathrm{C}$ 에서 평가한 시료에서 검출된 질소의 양이 더 높게 나타 나(Fig. 5(a)) 온도가 낮을수록 $\mathrm{Ni}$ 질화 현상이 가속화 되는 것으로 판단된다. 또한 평가 후 연료극을 $\mathrm{Ar}$ 분위 기에서 가열하면서 배출되는 가스를 질량분석기를 이용 하여 분석한 결과 질소가 방출됨을 확인하였으며, 이는 온도 증가에 따라 식 (12)와 같이 질화된 $\mathrm{Ni}$ 입자로부터 질소가 탈착되었기 때문이다. 온도가 증가함에 따라 방 출되는 질소의 스펙트럼 강도가 더욱 뚜렷하게 관찰됨 에 따라 질화된 $\mathrm{Ni}$ 입자가 고온으로 갈수록 불안정해지 면서 질소 탈착이 촉진된다고 추정된다(Fig. 5(b)).

$$
2 \mathrm{Ni}_{3} \mathrm{~N} \rightarrow 6 \mathrm{Ni}+\mathrm{N}_{2}
$$

또한, $\mathrm{Ni}_{3} \mathrm{~N}$ 상은 환원 분위기에서도 불안정하므로 식 (13)에 따라 수소 분위기에서 $\mathrm{Ni}$ 금속 상으로 분해될 수 있다.

$$
2 \mathrm{Ni}_{3} \mathrm{~N}+3 \mathrm{H}_{2} \rightarrow 6 \mathrm{Ni}+2 \mathrm{NH}_{3}
$$

질화 반응은 암모니아 분해 과정에서 발생할 수 있는 고유의 전이 상태이지만, DA-SOFC의 Ni-YSZ 연료극 에서 발생하게 되면 미세구조 변화를 초래하여 접촉저 항 증가, 전극의 반응성 감소 및 균열과 같은 물리적 결 함을 일으키고 그로 인해 단전지 성능 및 내구성 저하를 유발할 수 있다. ${ }^{[19,32]}$ 또한 $\mathrm{Ni}$ 질화에 의한 미세구조 변 형은 연료극의 표면뿐만 아니라 연료극 내 대부분의 $\mathrm{Ni}$ 입자들에서 발생한다. Stoeckl ${ }^{[32]}$ 등은 매니폴드를 이용 하여 대면적 평판형 단전지를 $700-800^{\circ} \mathrm{C}$ 암모니아 분 

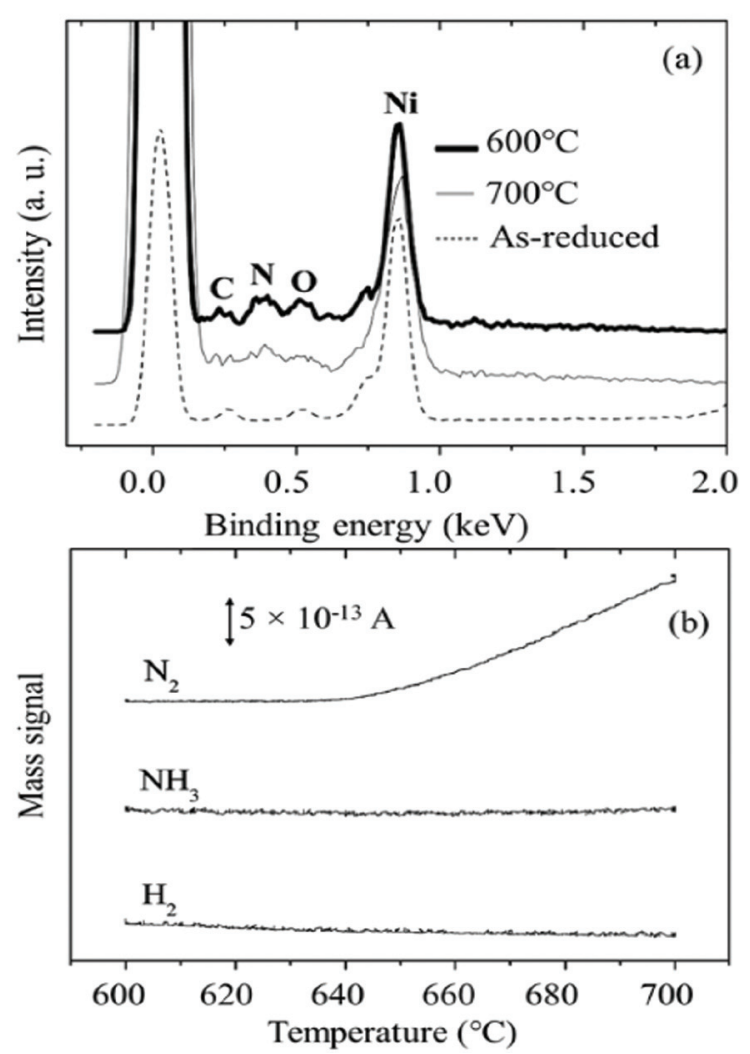

Fig. 5. (a) The EDS spectra of Ni-YSZ anode used in DASOFC fueled with $66.7 \% \mathrm{NH}_{3}-1.7 \% \mathrm{H}_{2} \mathrm{O}-31.6 \% \mathrm{~N}_{2}$ at $600^{\circ} \mathrm{C}$ and $700^{\circ} \mathrm{C}$ for $24 \mathrm{~h}$, respectively; (b) the mass spectra of flue gas generated when heating the used anode to $700^{\circ} \mathrm{C}$ in $\mathrm{Ar}$ at a heating rate of $10^{\circ} \mathrm{C} / \mathrm{min}$. Reproduced from Yang et al. ACS Appl Mater Interfaces 2015;7:28701-28707, with permission of ACS Publications [27].

위기에서 평가한 후 $\mathrm{Ni}-\mathrm{YSZ}$ 연료극과 $\mathrm{Ni}$ mesh 전류 집전체에 대한 미세구조 변화를 확인한 바 있다. 흥미롭 게도 매니폴드 출구 근처의 연료극보다 입구 부근의 연 료극에서 $\mathrm{Ni}$ 입성장이나 응집 현상이 두드러지게 확인 되었으며 이러한 변화는 연료극 내부나 표면에서 모두 관찰되었다(Figs. $6(\mathrm{a}-\mathrm{c})$ ). 또한 직경 $1 \mu \mathrm{m}$ 이하의 열 린 기공이나 닫힌 기공들이 생성되어 연료극의 부피 변 화를 초래하였다(Fig. 6(d)). 질화 반응에 따른 미세구조 변화는 $\mathrm{Ni}$ mesh 전류집전체에서 보다 두드러지게 나타 났는데, Fig. 6(e)와 같이 표면에 무수히 많은 미세 기 공들과 균열들이 관찰되었다. Alexander 등은 기공형
성 이유를 연료극의 $\mathrm{Ni}$ 이 질화 반응과 환원 반응을 거치 면서 발생하는 질소의 결합과 탈착에 기인한다고 설명 하였다. ${ }^{[50]}$ 더불어 질화 입자의 형성과 분해로 인해 $\mathrm{Ni}$ 입자의 수축과 팽창이 반복되면서 심한 경우 스트레스 에 의한 균열도 발생시키는 것으로 판단된다. 한편 수소 와 질소의 혼합가스에서 평가한 연료극의 $\mathrm{Ni}$ 입자에서 는 기공이나 균열 등은 관찰되지 않았다(Fig. 6(f)). 많 은 기공과 균열 등으로 인해 $\mathrm{Ni}$ 입자의 표면적은 증가 하여 암모니아 분해반응이 증가하였더라도 단전지 성능 증가는 미비하였는데, 이는 전기적 접촉이나 가스 확산 등이 악화되었기 때문이다. 결과적으로 $\mathrm{Ni}$ 촉매 입자의 반복적인 질화 및 환원 사이클은 연료극의 미세 구조를 변형시켜 삼상계면의 손실과 접촉저항의 증가를 초래하 였으며, 온도 사이클에 따라 연료극 표면 부근에서 균열 이 발생하여 결국 개회로전압과 출력이 감소하는 비가 역적인 단전지 성능 저하를 일으켰다. ${ }^{[27]}$ 이러한 $\mathrm{Ni}$ 질화 로 인한 입자의 미세구조 변화는 작동온도 감소에 따라 더욱 악화되는 것으로 나타났다. ${ }^{[19,32]}$

암모니아에 의한 질화 문제는 고온의 암모니아 분위 기에 노출되는 스택 부품인 금속분리판에서도 확인되었 다. Kishimoto 등은 $1 \mathrm{~kW}$ 급 DA-SOFC 스택을 1,000 시간 동안 평가한 후 연료극 분위기에 노출된 금속분리 판의 단면을 관찰하였다(Fig. 7). $\mathrm{Fe}-\mathrm{Cr}$ 페라이트계 스 테인리스스틸인 AISI430을 사용하였는데 SEM 관찰 결과로부터 $\mathrm{Fe}$ 원소가 풍부한 입자들이 모재로부터 분 리되어 표면에 분산되어 있는 심각한 표면 변형을 확 인하였다. 또한 해당 스택의 연료극 채널 영역에서 시 간에 따른 압력 손실을 측정하였을 때 손실이 점점 증 가하였다. ${ }^{[19]}$ 이는 금속분리막 표면으로부터 $\mathrm{Fe}$ 입자들 이 분리되어 연료극 유로 내부에 축적되면서 가스 흐름 을 방해하여 압력 손실을 증가시켰기 때문으로 추정된 다. Bianco 등은 SOFC 금속분리판 소재로 AISI441, Sanergy HT 및 Crofer $22 \mathrm{H}$ 와 같은 페라이트계 스테 인리스 스틸 표면을 플라즈마 질화(plasma nitriding) 처리한 후 고온 산화분위기에서의 미세구조 변화를 관 찰하였다. ${ }^{[51]}$ 페라이트계 스틸은 고온 산화 시, $\mathrm{Cr}$ 원 소가 빠르게 산화되어 모재 표면에 안정한 $\mathrm{Cr}$ 산화층 


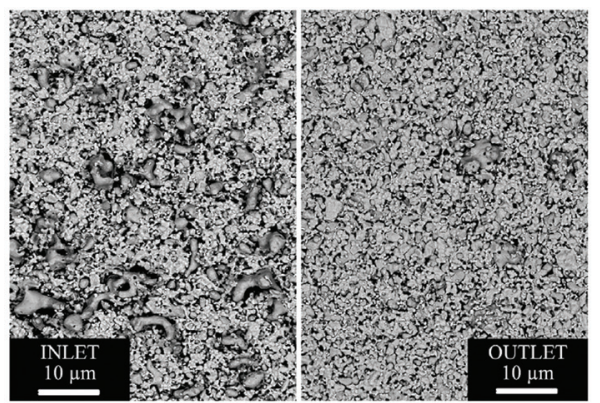

(a)

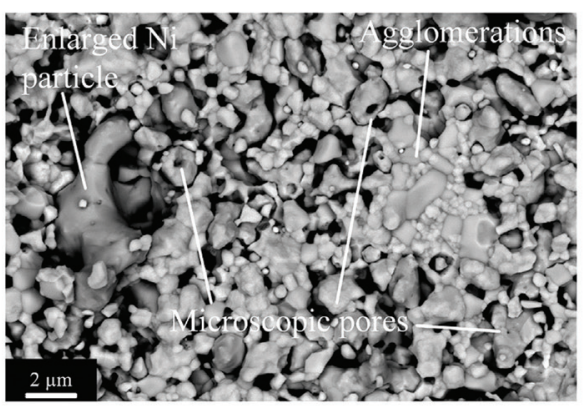

(b)

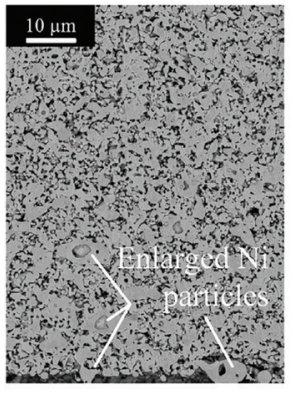

(c)

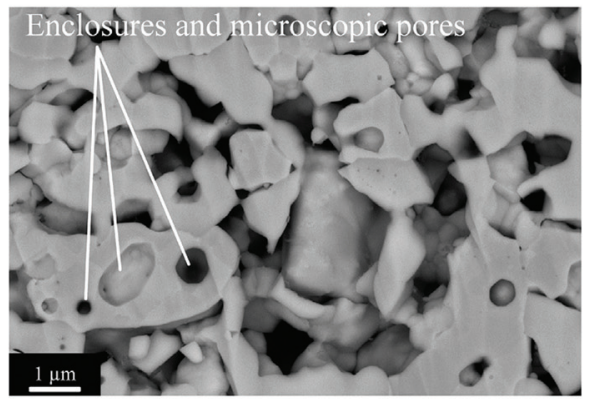

(d)

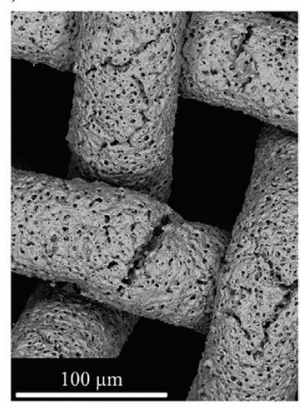

(e)

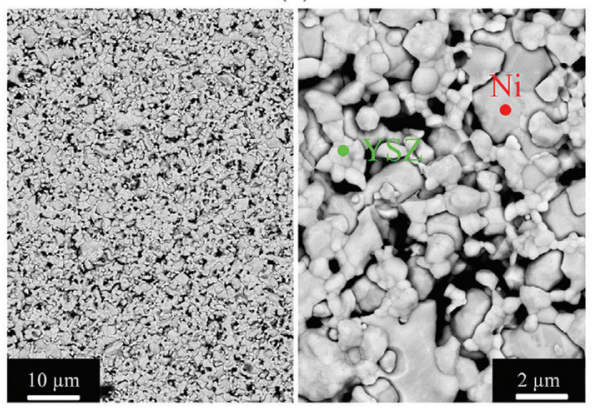

(f)

Fig. 6. Back scattered scanning electron microscopy images after the operation with ammonia based fuels at $700-800^{\circ} \mathrm{C}$. (a) SEM-images taken of the anode surface at the fuel inlet and outlet, (b) fuel inlet region in higher resolution and (c) the cross-sectional analysis of the anode in low and (d) high resolution as well as (e) the nickel contact mesh. (f) The anode surface after $\mathrm{H}_{2} / \mathrm{N}_{2}$ operation. Adapted from Stoeckl et al. Electrochim Acta 2019;298:874-883, with permission of Elsevier [32].

$\left(\mathrm{Cr}_{2} \mathrm{O}_{3}\right)$ 을 형성함으로써 산소의 확산에 의한 내부산화 를 억제하는 보호피막으로 작용하여 고온 내산화성을 향상시킨다. 하지만 질화 처리된 시료들은 산화속도가 빨라졌는데, $\mathrm{N}$ 가 모재 내부로 확산하면서 $\mathrm{Cr}$ 의 제거제 (scavenger)로써 $\mathrm{CrN}$ 이나 $\mathrm{Cr}_{2} \mathrm{~N}$ 과 같은 질화물을 형성 하기 때문이다. 특히 질소 편석(segregation)으로 인해 $\mathrm{Cr}$ 질화물은 주로 모재 입계에서의 형성되는데, ${ }^{[52]}$ 이 로 인해 모재 표면 근처의 입자에 일시적으로 $\mathrm{Cr}$ 원소
가 부족해져 보호파괴에 의한 $\mathrm{Fe}$ 부식이 진행된다. 즉 $\mathrm{Fe}$ 이 모재 외부로 확산해 나오면서 표면에 $\mathrm{Fe}$ 입자들이 일부 형성되게 된다. 하지만 $700^{\circ} \mathrm{C}$ 이상의 고온에서 $\mathrm{Cr}$ 함량이 18-24 wt\%로 충분히 높기 때문에 표면에서 신 속하게 $\mathrm{Cr}$ 산화피막이 성장하여 보호막 역할을 회복했 다고 설명하였다. ${ }^{[51]}$ 이러한 결과로부터 고온의 암모니 아 분위기에 노출된 페라이트계 스틸도 질화되면서 표 면에 보호피막을 형성하는 대신 모재 내부에 $\mathrm{Cr}$ 질화물 


\section{특 집 표 홍종은, 이승복, 조동우, 김혜성, 임탁형, 박석주, 송락현}
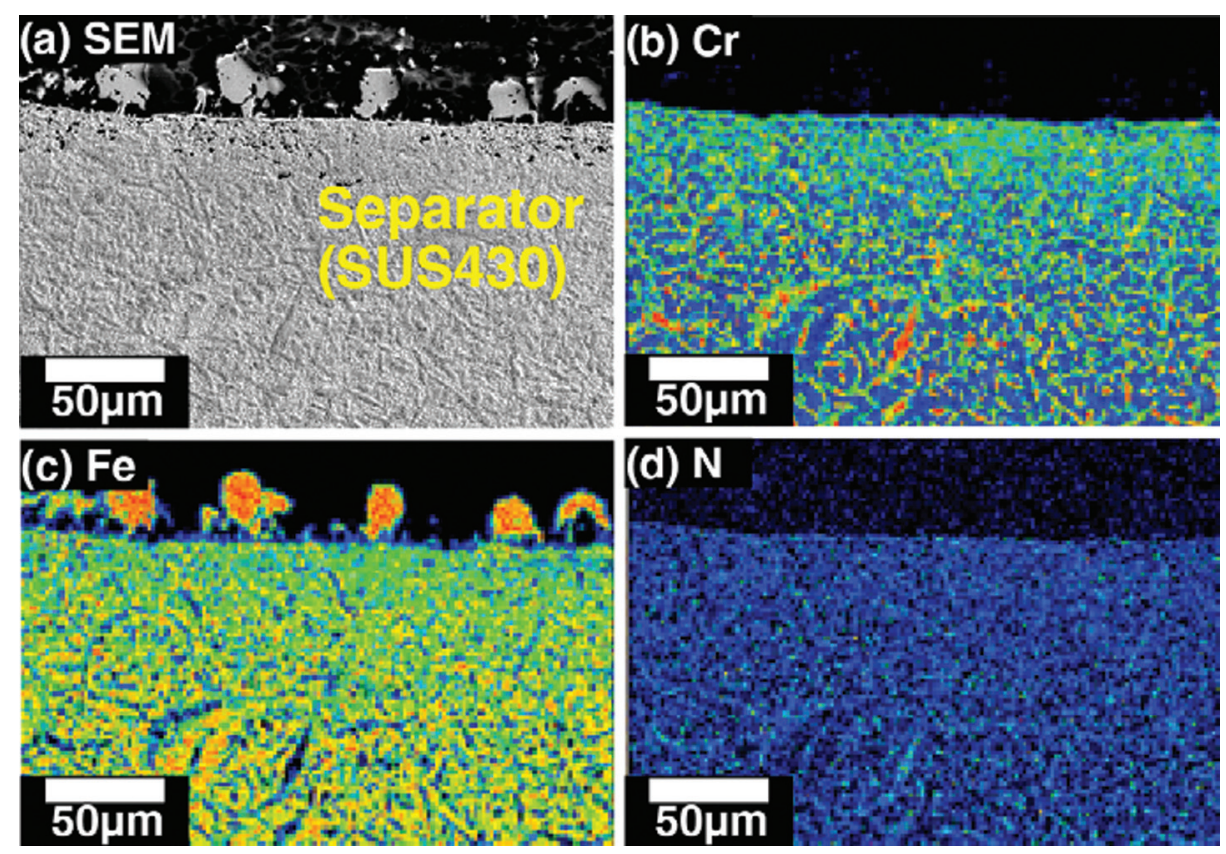

Fig. 7. Cross-sectional images of the separator on the anode side after 1,000 h durability test with direct ammonia fuel: (a) scanning electron microscopy image, and the EDS maps of (b) Cr, (c) Fe, and (d) N. Adapted from Kishimoto et al. Fuel Cells, 2020;20:80-88, with permission of Wiley [19].

을 형성하면서 $\mathrm{Fe}$ 입자가 표면으로 확산하여 부식될 수 있다. 하지만 연료극에서는 산소 분압이 공기극에 비해 현저히 낮기 때문에 고온이라 할지라도 모재 표면에 $\mathrm{Cr}$ 보호피막을 형성하는데 한계가 있을 것이므로 보호파 괴에 의한 $\mathrm{Fe}$ 부식이 지속적으로 발생할 것으로 추정된 다. 또한 모재 표면에 보호피막의 형성되지 않는 한 $\mathrm{N}$ 원자가 모재 내부로 지속적으로 확산하면서 $\mathrm{Cr}$ 질화물 을 형성하여 심한 경우 $\mathrm{N}$ 원소가 풍부한 영역에서 부분 적으로 오스테나이트 상전이를 유발할 가능성도 있다. 참고로 오스테나이트계 스틸은 페라이트계 스틸이나 $\mathrm{SOFC}$ 단전지 구성요소들 보다 열팽창계수가 크기 때 문에 균열이나 파괴와 같은 물리적 결함을 유발할 수 있 다. 한편 Stoeckle 등은 전해질 지지형 SOFC 단전지와 $\mathrm{CFY}(\mathrm{Cr}-\mathrm{Fe}-\mathrm{Y})$ 금속분리판을 이용한 숏스택을 제작하 여 $835^{\circ} \mathrm{C}$ 에서 $30 \%$ 가습된 암모니아 연료를 공급하여 장 기 내구성을 평가하였다. 1,000 시간 평가 후 $1.1 \% / \mathrm{kh}$ 열화율을 나타내었으며 오믹저항이 지속적으로 증가하 였다. 사후분석에서 앞선 경우와 비슷하게 Ni mesh에
서 미세기공들과 균열을 확인할 수 있었다. 또한 $\mathrm{CFY}$ 금속분리판에서도 모재의 두께 방향으로 $200 \mu \mathrm{m}$ 이상 $\mathrm{N}$ 이 확산하여 내부에 $\mathrm{Cr}$ 질화물을 형성한 반편 모재 표 면에 얇고 연속적인 $\mathrm{Cr}$ 산화층을 형성하여 이로 인해 접 촉저항이 증가되었다고 보고하였다. ${ }^{[53]}$ 다만 $\mathrm{CFY}$ 합금 은 $\mathrm{Fe}$ 함량이 적어 페라이트계 스틸과 비교했을 때 표 면에서 $\mathrm{Fe}$ 부식은 확인되지 않았다. 결론적으로 $\mathrm{DA}-$ $\mathrm{SOFC}$ 스택에 사용하는 금속분리판 표면의 구조적 변 화에 의해 단기적으로는 스택 성능에 대한 심각한 영향 이 확인되진 않았지만, 장기적으로는 연료극 내 가스 유 동을 국부적으로 감소시키거나 차단시켜 분극저항을 증 가시킬 수 있다. 또한 금속분리판 표면 부식이나 산화에 의해 접촉저항이 지속적으로 증가하거나 물리적 변형이 발생하여 스택의 급격한 성능 저하를 유발할 수도 있다. 그러므로 스택 내구성 향상을 위해 금속분리판 표면의 질화 문제 개선이 필수적이며, 이를 위해 질화에 내저항 성을 갖는 신규 소재 개발이나 첨가제 또는 질화 억제를 위한 보호 코팅 기술 개발 등을 고려해야 할 것이다. 
추가로 앞서 설명한 바와 같이 $\mathrm{DA}-\mathrm{SOFC}$ 스택에서 암모니아 분해반응은 연료 주입구 인근의 연료극에서 집중적으로 발생하여 국부적인 온도 감소가 발생하므로 스택 내 열 분포나 유동의 불균형을 초래하여 열 충격에 의한 물리적 결함이나 성능 저하를 유발할 수 있을 것이 다. Stockle 등은 연료극과 공기극 유로에 대한 가스 공 급 방식에 따라 co-flow에 비해 counter-flow인 경우 오믹저항과 가스 확산에 의한 분극저항이 다소 감소되 어 성능이 향상된다고 보고하였다. ${ }^{[32]}$ 한편 $\mathrm{SOFC}$ 시스 템은 운전 중 수소의 산화반응에 의해 스택에서 발생하 는 열을 냉각시키기 위해 공기극에 유량을 과도하게 공 급하기도 하는데 암모니아 분해반응에 의한 온도 감소 현상을 적절히 이용한다면 냉각에 필요한 에너지를 감 소시켜 시스템 효율 향상에 기여할 수 있을 것이다. 따 라서 암모니아 분해반응을 기반으로 한 스택 및 시스템 해석과 설계 기술 개발이 필요할 것으로 판단된다.

$\mathrm{SOFC}-\mathrm{O}$ 에 암모니아 연료를 사용할 경우 연료극에 서 암모니아의 전기화학적 산화가 발생한다면 반응생성 물로 $\mathrm{NO}$ 또는 $\mathrm{N}_{2} \mathrm{O}$ 같은 질소 산화물이 발생할 수 있다. Staniforth 등은 암모니아의 직접적인 산화반응과 수소 산화반응에 대한 열역학적 에너지로부터 이론적인 개회 로전압을 계산하였다. 이를 통해 DA-SOFC 연료극에 서 암모니아 산화반응이 일어난다면작동 온도가 증가할 수록 단전지의 개회로전압이 증가하고, 수소 산화반응 이 일어난다면 개회로전압이 감소할 것이라고 설명하였 다. ${ }^{[54]}$ 하지만 DA-SOFC 실험 결과들에 따르면 작동 온 도가 증가할수록 개회로전압이 점차 감소하는 것으로 나타났다. ${ }^{[27,27,32,54]}$ 더불어 $850^{\circ} \mathrm{C}$ 에서 $\mathrm{Ni}-\mathrm{YSZ}$ 연료극을 적용한 $\mathrm{DA}-\mathrm{SOFC}$ 의 연료 배가스를 질량분석기로 분석 하였을 때 어떠한 질소 산화물도 검출되지 않음을 실험 적으로 확인한 바 있다. ${ }^{[33,54]}$ 따라서 $\mathrm{DA}-\mathrm{SOFC}$ 연료극 에서는 암모니아 분해반응에 의해 생성된 수소의 산화 반응이 주요함을 예상할 수 있으며, 암모니아의 산화반 응으로 인한 질소 화합물 생성 가능성은 낮은 것으로 예 상된다. 다만 촉매의 종류나 작동 조건 등에 따라 암모 니아 산화반응을 통해 질소 화합물이 생성될 가능성을 완전히 배제할 수 없기 때문에 DA-SOFC 촉매 및 연료
극 소재 개발 시 지속적인 확인이 필요할 것이다. 한편 암모니아는 연소 반응에 의해 질소 화합물이 생성될 수 있기 때문에 ${ }^{[5]} \mathrm{DA}-\mathrm{SOFC}$ 시스템에서는 연료 배가스 중 분해되지 않은 암모니아가 존재할 경우, 최종 배출 전에 완전히 분해 또는 연소시켜 질소와 수증기만 배출하고 해로운 질소 화합물은 생성되지 않도록 암모니아 잔류 가스를 처리하기 위한 촉매 반응기 및 운전조건 최적화 기술 개발이 필요할 것이다. ${ }^{[55]}$

아울러 암모니아는 독성 물질이기 때문에 SOFC 연료 로 사용할 경우 누출 사고에 대한 잠재적 위험성과 사용 자 접촉에 대한 안전 문제를 고려하여 반드시 사전에 안 전관리방안을 수립해야 할 것이다.

\section{5. 결론}

청정 발전을 위한 많은 연료들 중 암모니아는 탄소 배 출이 없으며 수소에 비해 저장 및 운송이 간편하고 분리 나 정제 없이 $\mathrm{SOFC}$ 연료로 직접 사용하여 고효율 발전 이 가능하다. 그러므로 고성능 DA-SOFC 개발을 위해 서는 연료극에서의 암모니아 분해 및 전기화학적 수소 산화반응에 대한 율속단계반응 규명을 통해 최적의 촉 매 소재를 설계, 개발하고 이를 효율적으로 연료극에 적 용하는 방안을 모색해야 할 것이다. 양산화에 필요한 내 구성 확보를 위해서는 상용 $\mathrm{SOFC}$ 소재 및 스택 부품들 에서 확인된 암모니아 연료 조건에서의 열화 현상들에 대한 발생 원리를 충분히 이해하여 이를 개선하거나 억 제할 수 있는 기술 개발도 필요하다. 또한 암모니아 연 료의 반응 특성에 따른 열 분포 및 유동 해석과 검증을 통해 최적의 스택 설계 기술을 개발하고 이를 반영한 $\mathrm{DA}-\mathrm{SOFC}$ 시스템 설계를 도출해야 할 것이다. 그리고 $\mathrm{DA}-\mathrm{SOFC}$ 시스템의 양산화를 촉진하기 위해서는 기존 에 구축된 암모니아 저장 및 공급 설비를 중심으로 설 치, 운영할 수 있는 분산 발전형 시스템 개발에 초점을 맞춰 기술 개발 방안을 수립하는 것이 유망할 것이다. 양산화 기술 개발과 더불어 암모니아 연료를 안전하게 활용할 수 있는 관리기준과 시스템에 대한 인증, 표준화 방안 및 현행 제도상 규제 등에 대해서도 면밀한 검토가 
필요할 것이다.

\section{Acknowledgement}

본 결과물은 농림축산식품부의 재원으로 농림식품기 술기획평가원의 농업에너지 자립형 산업모델 기술개발 의 지원을 받아 연구되었습니다(120095031SB010).

\section{REFERENCES}

1. A. Afif, N. Radenahmad, Q. Cheok, S. Shams, J.H. Kim, and A.K. Azad, "Ammonia-fed fuel cells: A comprehensive review," Renew. Sustain. Energy Rev., 60 822-835 (2016).

2. H. Lund, "Renewable energy strategies for sustainable development," Energy, 32 912-919 (2007).

3. O. Siddiqui and I. Dincer, "A review and comparative assessment of direct ammonia fuel cells," Therm. Sci. Eng. Prog., 5 568-578 (2018).

4. N.Q. Minh, "Ceramic fuel cells," J. Am. Ceram. Soc., 76 563-588 (1993).

5. H. Lee, Y. Woo, and M.J. Lee, "The needs for R\&D of ammonia combustion technology for carbon neutrality - Part II R\&D trends and technical feasibility analysis(in Korean)," J. Korean Soc. Combust. 26 [1] 84-106 (2021).

6. I. Dincer, "Technical, environmental and exergetic aspects of hydrogen energy systems," Int. J. Hydrogen Energy, 27 265-285 (2002).

7. I. Dincer, "Environmental and sustainability aspects of hydrogen and fuel cell systems," Int. J. Energy Res., 31 29-55 (2007).

8. O. Siddiqui and I. Dincer, "Development of a new ammonia-based energy storage option for grid balancing," Energy Storage, 2 [4] 1-13 (2020).

9. G.W. Crabtree and M.S. Dresselhaus, "The hydrogen fuel alternative,” MRS Bull., 33 421-428 (2008).

10. S.B. Walker, M. Fowler, and L. Ahmadi, "Comparative life cycle assessment of power-to-gas generation of hydrogen with a dynamic emissions factor for fuel cell vehicles," J. Energy Storage, 4 62-73(2015).

11.S. Uhm, M. Seo, and J. Lee, "Review:
Competitiveness of formic acid fuel cells: In comparison with methanol(in Korean)," J. Korean Ind. Eng. Chem., 27 123-127 (2016).

12. M.C.J. Bradford, P.E. Fanning, and M.A. Vannice, "Kinetics of $\mathrm{NH}_{3}$ Decomposition over Well Dispersed Ru,” J. Catal., 172 479-484 (1997).

13. D.G. L€offler and L.D. Schmidt, "Kinetics of $\mathrm{NH}_{3}$ decomposition on polycrystalline Pt," J. Catal., 41 440-454 (1976).

14. A. Alera-Medina, H. Xiao, M. Owen-Jones, W.I.F. David, and P.J. Bowen, “Ammonia for power," Prog. Energy Combust. Sci., 69 63-102 (2018).

15. R. Lan and S. Tao, "Ammonia as a suitable fuel for fuel cells,” Front. Energy Res., 2 1-4 (2014).

16. M. Xue, Q. Wang, B.-L. Lin, and K. Tsunemi, "Assessment of ammonia as an energy carrier from the perspective of carbon and nitrogen footprints," ACS Sustain. Chem. Eng., 7 12494-12500 (2019).

17. W.C. Tan, H. Iwai, M. Kishimoto, G. Brus, J.S. Szmyd, and H. Yoshida, "Numerical analysis on effect of aspect ratio of planar solid oxide fuel cell fueled with decomposed ammonia,'J. Power Sources, 384 367-378 (2018).

18. M.F. Ezzat and I. Dincer, "Comparative assessments of two integrated systems with/without fuel cells utilizing liquefied ammonia as a fuel for vehicular applications," Int. J. Hydro. Energy, 43 4597-4608 (2018).

19. M. Kishimoto, H. Muroyama, S. Suzuki, M. Saito, T. Koide, Y. Takahashi, T. Horiuchi, H. Yamasaki, S. Matsumoto, H. Kubo, N. Takahashi, A. Okabe, S. Ueguchi, M. Jun, A. Tateno, T. Matsuo, T. Matsui, H. Iwai, H. Yoshida, and K. Eguchi, "Development of 1 kW-class ammonia fueled solid oxide fuel cell stack," Fuel Cells, 20 80-88 (2020).

20. T. Okanishi, K. Okura, A. Srifa, H. Muroyama, T. Matsui, M. Kishimoto, M. Saito, H. Iwai, H. Yoshida, M. Saito, T. Koide, H. Iwai, S. Suzuki, Y. Takahashi, T. Horiuchi, H. Yamasaki, S. Matsumoto, S. Yumoto, H. Kubo, J. Kawahara, A. Okabe, Y. Kikkawa, T. Isomura, and K. Eguchi, "Comparative study of ammonia-fueled solid oxide fuel cell systems," Fuel Cells, 17 383-390 (2017).

21. G. Jeerh, M. Zhang, and S. Tao, "Recent progress in ammonia fuel cells and their potential applications," J. Mater. Chem. A, 9 727-752 (2021). 
22. D. Jeong and G. Kim, "Solid oxide fuel cell and application of proton conducting ceramics(in Korean)," Ceramist, 21 [4] 366-377 (2018).

23. Z. Wan, Y. Tao, J. Shao, Y. Zhang, and H. You, "Ammonia as an effective hydrogen carrier and a clean fuel for solid oxide fuel cells," Energy Convers. Manag., 228113729 (2021).

24. S.P.S. Shaikh, A. Muchtar, and M.R. Somalu, "A review on the selection of anode materials for solidoxide fuel cells," Renew. Sust. Energ. Rev., 51 1-8 (2015).

25. A.F.S. Molouk, J. Yang, T. Okanishi, H. Muroyama, T. Matsui, and K. Eguchi, "Comparative study on ammonia oxidation over Ni-based cermet anodes for solid oxide fuel cells," J. Power Sources, 305 72-79 (2016).

26. J.C. Ganley, F.S. Thomas, E.G. Seebauer, and R.I. Masel, "A priori catalytic activity correlations: The difficult case of hydrogen production from ammonia," Catal. Letters, 96 117-122 (2004).

27. J. Yang, A.F.S. Molouk, T. Okanishi, H. Muroyama, T. Matsui, and K. Eguchi, "A stability study of Ni/ Yttria-stabilized zirconia anode for direct ammonia solid oxide fuel cells," ACS Appl. Mater. Interfaces, 7 28701-28707 (2015).

28. J. Zhang, H. Xu, and W. Li, "Kinetic study of $\mathrm{NH}_{3}$ decomposition over Ni nanoparticles: The role of La promoter, structure sensitivity and compensation effect," Appl. Catal. A: Gen., 296 257-267 (2005).

29. A.F.S. Molouk, T. Okanishi, H. Muroyama, T. Matsui, and K. Eguchi, "Electrochemical and catalytic behaviors of Ni-YSZ anode for the direct utilization of ammonia fuel in solid oxide fuel cells, J. Electroehcm. Soc., 162 [10] F1268-F1274 (2015).

30. Y. Wang, J. Yang, J. Wnag, W. Guan, B. Chi, L. Jia, J, Chen, H. Muroyama, To. Matsui, and K. Eguchi, "Low-temperature ammonia decomposition catalysts for direct ammonia solid oxide fuel cells," J. Electrochem. Soc., 167064501 (2020).

31. G. Cinti, G. Discepoli, E. Sisani, and U. Desideri, "SOFC operating with ammonia: Stack test and system analysis," Int. J. Hydro. Energy, 41 [31] 13583-13590 (2016).

32. B. Stoeckl, V. Subotic, M. Preininger, M. Schwaiger, N. Evic, H. Schroettner, and C. Hochenauer, "Characterization and performance evaluation of ammonia as fuel for solid oxide fuel cells with $\mathrm{Ni} /$ YSZ anodes," Electrochim. Acta 298 874-883 (2019).

33. A. Hagen, H. Langnickel, and X. Sun, "Operation of solid oxide fuel cells with alternative hydrogen carriers," Int. J. Hydro. Energy, 44 18382-183922 (2019).

34. S.S. Shy, S.C. Hsieh, and H.Y. Chang, "A pressurized ammonia-fueled anode-supported solid oxide fuel cell: Power performance and electrochemical impedance measurements," J. Power Sources, 396 80-87 (2018).

35. B.C. Gates, "Supported metal-clusters-synthesis, structure, and catalysis," Chem. Rev., 95 511-522 (1995).

36. A.Y. Stakheev and L.M. Kustov, "Effects of the support on the morphology and electronic properties of supported metal clusters: Modern concepts and progress," Appl. Catal. A: Gen., 188 [1999] 3-35 (1990).

37. A.K. Hill and L. Torrente-Murciano, "Low temperature $\mathrm{H}_{2}$ production from ammonia using ruthenium-based catalysts: Synergetic effect of promoter and support," Appl. Catal. B, 172-173 129135 (2015).

38. A.K. Hill and L. Torrente-Murciano, "In-situ $\mathrm{H}_{2}$ production via low temperature decomposition of ammonia: Insights into the role of cesium as a promoter," Int. J. Hydro. Energy, 39 7646-7654 (2014).

39. S.F. Yin, B.Q. Xu, X.P. Zhou, and C.T. Au, "A mini-review on ammonia decomposition catalysts for on-site generation of hydrogen for fuel cell applications," Appl. Catal. A: Gen., 277 1-9 (2004).

40. G. Meng, C. Jiang, J. Ma, Q. Ma, and X. Liu, "Comparative study on the performance of a SDCbased SOFC fueled by ammonia and hydrogen," J. Power Sources, 173 189-193 (2007).

41. W. Raróg-Pilecka, E. Miśkiewicz, D. Szmigiel, and Z. Kowalczyk, "Structure sensitivity of ammonia synthesis over promoted ruthenium catalysts supported on graphitised carbon," J. Catal., 231 11-19 (2005).

42. W. Zheng, J. Zhang, H. Xu, and W. Li, " $\mathrm{NH}_{3}$ decomposition kinetics on supported Ru clusters: Morphology and particle size effect," Catal. Letters, 119 311-318 (2007). 
43. A.M. Karim, V. Prasad, G. Mpourmpakis, W.W. Lonergan, A.I. Frenkel, J.G. Chen, and D.G. Vlachos, "Correlating particle size and shape of supported $\mathrm{Ru} /$ $\gamma-\mathrm{Al}_{2} \mathrm{O}_{3}$ catalysts with $\mathrm{NH}_{3}$ decomposition activity," J. Am. Chem. Soc., 131 12230-12239 (2009).

44. X.-K. Li, W.-J. Ji, J. Zhao, S.-J. Wang, and C.-T. Au, "Ammonia decomposition over Ru and Ni catalysts supported on fumed $\mathrm{SiO}_{2}, \mathrm{MCM}-41$, and SBA-15," J. Catal., 236 181-189 (2005).

45. J. Zhang, H. Xu, X. Jin, Q. Ge, and W. Li, "Characterizations and activities of the nanosized $\mathrm{Ni} / \mathrm{Al}_{2} \mathrm{O}_{3}$ and $\mathrm{Ni} / \mathrm{La}-\mathrm{Al}_{2} \mathrm{O}_{3}$ catalysts for $\mathrm{NH}_{3}$ decomposition," Appl. Catal. A: Gen., 290 87-96 (2005).

46. H. Liu, H. Wang, J. Shen, Y. Sun, and Z. Liu, "Preparation, characterization and activities of the nano-sized Ni/SBA-15 catalyst for producing $\mathrm{CO}_{x^{-}}$ free hydrogen from ammonia," Appl. Catal. A: Gen., 337 138-147 (2008).

47. J.H. Kim, J.K. Kim, and W.C. Jung, "Development and application of ex-solution nanocatalyst(in Korean)," Ceramist, 23 [2] 200-210 (2020).

48. R. Huang, H.J. Kim, and J.W. Han, “A review of smart exsolution catalysts for the application of gas phase reactions(in Korean)," Ceramist, 23 [2] 211230 (2020).

49. N. Mahato, A. Banerjee, A. Gupta, S. Omar, and K.
Balani "Progress in material selection for solid oxide fuel cell technology: A review,“ Prog. Mater. Sci., 72 141-337 (2015).

50. A.-M. Alexander, J.S.J. Hargreaves, and C. Mitchell, "The reduction of various nitrides under hydrogen: $\mathrm{Ni}_{3} \mathrm{~N}, \mathrm{Cu}_{3} \mathrm{~N}, \mathrm{Zn}_{3} \mathrm{~N}_{2}$ and $\mathrm{Ta}_{3} \mathrm{~N}_{5}$," Top. Catal. 55 [14-15] 1046-1053 (2012).

51. M. Bianco, S. Poitel, J.E. Hong, S. Yang, Z,J. Wang, M. Willinger, R. Steinberger-Wilckens, and J. Van herle, "Corrosion behaviour of nitrided ferritic stainless steels for use in solid oxide fuel cell devices," Corros. Sci., 165108414 (2020).

52. R.J. Hodges, "Intergranular corrosion in high purity ferritic stainless steels: Effect of cooling rate and alloy composition," Corrosion, 27 [3] 119-127 (1971).

53. B. Stoeckl, M. Preininger, V. Subotić, S. Megel, C. Folgner, and C. Hochenauer, "Towards a wastewater energy recovery system: The utilization of humidified ammonia by a solid oxide fuel cell stack," J. Power Sources, 450227608 (2020).

54. J. Staniforth and R.M. Ormerod, "Clean destruction of waste ammonia with consummate production of electircal power within a solid oxide fuel cell system," Green Chem., 5 606-609 (2003).

55. https://www.fraunhofer.de/en/press/researchnews/2021/march-2021/worlds-first-hightemperatureammonia-powered-fuel-cell-for-shipping.html

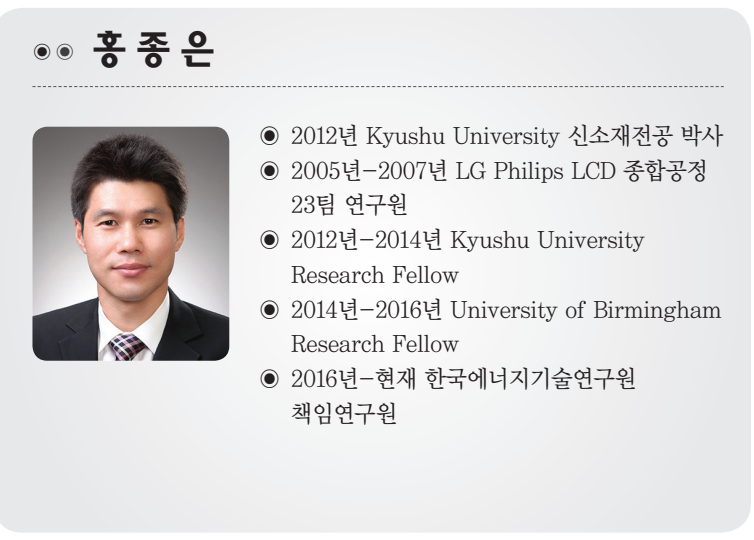

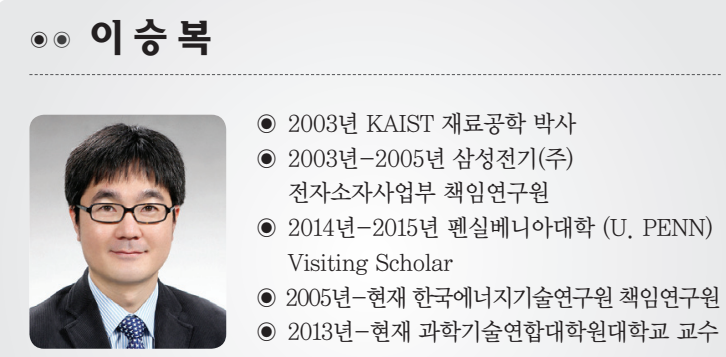




\section{으조 동우}

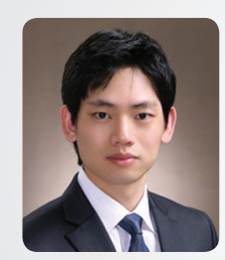

- 2013년 연세대학교 신소재전공 공학석사

- 2014년 한국생산기술연구원 석사후연구원

0 2019년 대구경북과학기술원 에너지전공 공학박사

( 2019년-현재 한국에너지기술연구원 선임기술원

\section{○○ 김혜성}

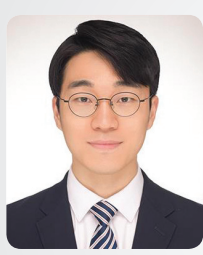

- 2019년 KAIST 신소재전공 박사

- 2018년-현재 한국에너지기술연구원 선임연구원

\section{○。 임탁형}

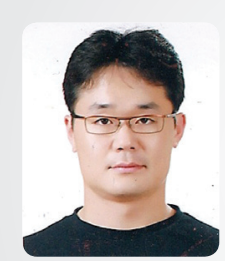

( 2004년 KAIST 생명화학공학 박사

( 2004년-현재 한국에너지기술연구원 책임연구원

( 2013년-현재 과학기술연합대학원대학교 교수

\section{○。 송 락현}

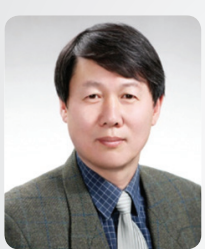

( 1990년 KAIST 재료공학 박사

( 2006년 미국 University of South Carolina Visiting Scholar

( 1991년-현재 한국에너지기술연구원 책임연구원

- 2013년-현재 과학기술연합대학원대학교 교수

( 2015년-현재 한국수소및신에너지학회 부회장

\section{○。 박 석 주}

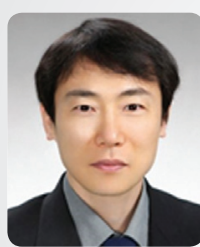

( 1999년 KAIST 기계공학 박사

- 2000년 미국 University of Minnesota Post Doc.

- 2000년-현재 한국에너지기술연구원 책임연구원

( 2013년-현재 과학기술연합대학원대학교 교수 